OPEN ACCESS

Edited by:

Min Ye,

Peking University, China

Reviewed by:

Helen Skaltsa,

National and Kapodistrian University of

Athens, Greece

Giuseppe Annunziata,

University of Naples Federico II, Italy

${ }^{*}$ Correspondence:

Yibin Feng

yfeng@hku.hk

Specialty section: This article was submitted to

Ethnopharmacology,

a section of the journal

Frontiers in Pharmacology

Received: 31 December 2019

Accepted: 09 March 2020

Published: 24 March 2020

Citation:

Li S, Xu Y, Guo W, Chen F, Zhang C, Tan HY, Wang N and Feng Y (2020)

The Impacts of Herbal Medicines

and Natural Products on Regulating

the Hepatic Lipid Metabolism.

Front. Pharmacol. 11:351.

doi: 10.3389/fphar.2020.00351

\section{The Impacts of Herbal Medicines and Natural Products on Regulating the Hepatic Lipid Metabolism}

\author{
Sha Li, Yu Xu, Wei Guo, Feiyu Chen, Cheng Zhang, Hor Yue Tan, Ning Wang \\ and Yibin Feng * \\ School of Chinese Medicine, Li Ka Shing Faculty of Medicine, The University of Hong Kong, Hong Kong, Hong Kong
}

The dysregulation of hepatic lipid metabolism is one of the hallmarks in many liver diseases including alcoholic liver diseases (ALD) and non-alcoholic fatty liver diseases (NAFLD). Hepatic inflammation, lipoperoxidative stress as well as the imbalance between lipid availability and lipid disposal, are direct causes of liver steatosis. The application of herbal medicines with anti-oxidative stress and lipid-balancing properties has been extensively attempted as pharmaceutical intervention for liver disorders in experimental and clinical studies. Although the molecular mechanisms underlying their hepatoprotective effects warrant further exploration, increasing evidence demonstrated that many herbal medicines are involved in regulating lipid accumulation processes including hepatic lipolytic and lipogenic pathways, such as mitochondrial and peroxisomal $\beta$-oxidation, the secretion of very low density lipoprotein (VLDL), the non-esterified fatty acid (NEFA) uptake, and some vital hepatic lipogenic enzymes. Therefore, in this review, the pathways or crucial mediators participated in the dysregulation of hepatic lipid metabolism are systematically summarized, followed by the current evidences and advances in the positive impacts of herbal medicines and natural products on the lipid metabolism pathways are detailed. Furthermore, several herbal formulas, herbs or herbal derivatives, such as Erchen Dection, Danshen, resveratrol, and berberine, which have been extensively studied for their promising potential in mediating lipid metabolism, are particularly highlighted in this review.

Keywords: herbal medicines, natural products, lipid metabolism, fatty liver, lipolysis, lipogenesis

\section{INTRODUCTION}

Generally, liver regulates lipid metabolism by three major processes: (1) uptake free fatty acids from circulation, and de novo fatty acid synthesis (FAS); (2) lipid storage, including converting fatty acids into triglyceride (TG) and other lipid droplets, which are subsequently exported to adipose tissue or stored in liver; and (3) lipid consumption, including lipolysis, $\beta$-oxidation, and the generation of lipoproteins (Reddy and Rao, 2006; Musso et al., 2009; Ponziani et al., 2015; Mato et al., 2019). These processes are presented in Figure 1. Correct control of lipid level is critical for cellular and organismal homeostasis, while interferences with the lipogenic pathways are accompanied with a variety of metabolic syndromes. The disorders of lipid metabolism, such as decreased $\beta$-oxidation, 


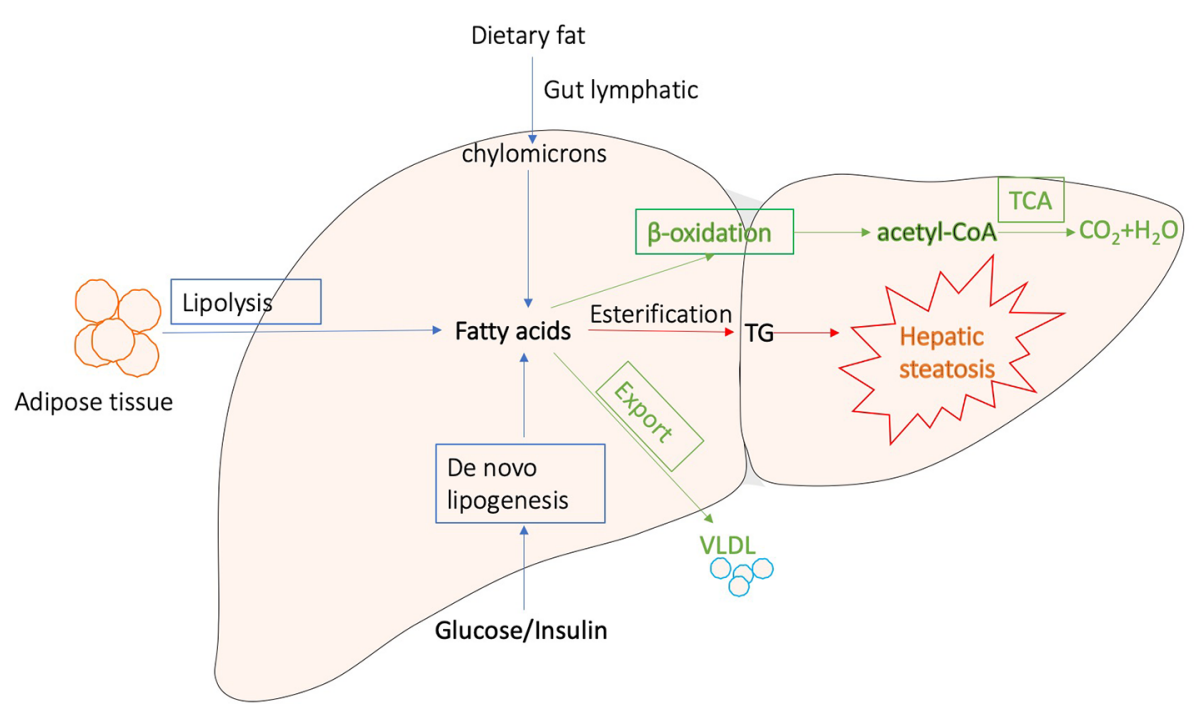

FIGURE 1 | Major processes involved in hepatic lipid metabolism.

enhanced lipolysis, and secretion of very low-density lipoprotein (VLDL), as well as altered pathways involved in the FAS, drive the accumulation of lipid droplets into the hepatocytes, eventually leading to the development of hepatic steatosis, which is a common pathological feature in various liver diseases (Reddy and Rao, 2006; Nguyen et al., 2008; Tessari et al., 2009; Perla et al., 2017).

The most prevalent liver diseases resulting from lipid metabolism disorder are alcoholic and non-alcoholic fatty liver diseases. Except difference in alcohol consumption, alcoholic and non-alcoholic fatty liver diseases show similar pathological process, which is characterized by long-term excessive fat accumulation in the liver (Younossi, 2019). They represent a wide range of liver injury, from simple fatty liver through steatosis with necrosis and inflammation to fibrosis and cirrhosis (Lomonaco et al., 2013; Heeboll et al., 2018). In particular, non-alcoholic fatty liver diseases (NAFLD), as the metabolic diseases induced by obesity and type 2 diabetes mellitus, are the second leading causes of death globally, becoming a heavy economic burden in many countries due to the high prevalence (Albhaisi and Sanyal, 2018; Al-Dayyat et al., 2018). Since inordinate lipid metabolism is intensively involved in fatty liver diseases progression, reducing lipid accumulation is a major target of development of pharmaceutical agents for various liver diseases (Ipsen et al., 2018). Simvastatin has been used as lipidlowing drug in patients with hyperlipidemia (Aronow, 2006). However, it shows side effects, such as constipation headaches, nausea, myopathy, elevated blood sugar, and even liver damage. As a matter of fact, there is currently no satisfying therapeutic drug for fatty liver diseases (Issa et al., 2018; Moctezuma-Velazquez, 2018).

Over the past decades, due to the positive efficacy and minimal side effects, herbal medicines, and natural products have obtained increasing attention as alternative therapeutic agents for liver disorders and dyslipidemia (Xiao et al., 2013; Yao et al., 2016; Liu Q. et al., 2017). Growing evidence from preclinical studies suggests that many herbs and isolated compounds could inhibit the progression of hepatic steatosis (Dong et al., 2012; Liu Z. L. et al., 2013). A variety of mechanisms have been demonstrated to be implicated in preventing hepatic steatosis, including reducing lipogenesis, enhancing $\beta$-oxidation, increasing insulin sensitivity, suppressing oxidative stress, and inhibiting activation of inflammatory pathways (Dong et al., 2012; Yao et al., 2016). In recent studies, sterol regulatory elementbinding protein 1c (SREBP1c), peroxisome proliferator activated receptor $\alpha$ (PPAR $\alpha)$, AMPactivated protein kinase (AMPK) and sirtuin 1 (SIRT1) signaling pathways have been highlighted as crucial molecular targets of action mechanisms by which herbal medicines regulate hepatic lipid metabolism (Liu Z. L. et al., 2013). In this review, herbal medicines involved in regulating hepatic lipolytic and lipogenic pathways, such as mitochondrial and peroxisomal $\beta$-oxidation, the secretion of very low-density lipoprotein (VLDL), the nonesterified fatty acid (NEFA) uptake, and some vital hepatic lipogenic enzymes are summarized. Current clinical evidences and meta-analysis in the positive impacts of herbal medicines on the hepatic lipid metabolism pathways have also been reviewed. Furthermore, several herbal formulae, herbs or herbal derivatives, such as Erchen Dection, Danshen, resveratrol, and berberine which have been extensively studied for their promising potential in mediating lipid metabolism, are particularly highlighted in this review. This review aims to update and summarize current evidence from laboratory and clinic studies to provide alternative and complementary medical therapies with the regulatory property of hepatic lipid metabolism to current pharmaceuticals for the treatment of liver diseases. 


\section{HERBAL MEDICINES AND NATURAL PRODUCTS REGULATE ON THE HEPATIC LIPID METABOLISM PATHWAYS}

Increasing evidence indicated that many herbs, natural products, and their derived compounds could inhibit the progression of hepatic steatosis. A variety of mechanisms have been demonstrated to be implicated in preventing hepatic steatosis and modulating lipid metabolism by herbs, including anti-oxidative stress, anti-inflammation, reducing hepatocyte fatty acid uptake and trafficking, reducing hepatic de novo lipogenesis, increasing lipolysis, induction of lipophagy, enhancing fatty acid $\beta$-oxidation. In particular, SREBP-1c, PPAR $\alpha$, AMPK, and SIRT1 signaling pathways have been highlighted as crucial molecular targets of action mechanisms by which herbal medicines regulate hepatic lipid metabolism. In Table 1, we reviewed the effects and mechanisms of herbs and some natural products on fatty liver diseases from recent studies. In the following section, we will discuss herbs that attenuate hepatic steatosis via reducing hepatocyte fatty acid uptake and trafficking, reducing hepatic de novo lipogenesis, increasing lipolysis, induction of lipophagy, and enhancing fatty acid $\beta$-oxidation in detail.

\section{Reducing Hepatocyte Fatty Acid Uptake and Trafficking}

Nonesterified fatty acids (NEFAs) and glycerol are generated and released from adipose tissue via lipolysis (Kawano and Cohen, 2013). Then NEFAs enter into hepatocytes principally through CD36, and fatty acid transports (FATPs)(Kawano and Cohen, 2013). Several mediators have been demonstrated to play a role in regulating CD36 and FATPs, such as pregnane $\mathrm{X}$ receptor (PXR), which impact the hepatocyte fatty acid uptake. Increasing evidence has shown that a variety of herbs and natural compounds attenuate hepatic steatosis via modulating genes for fatty acid uptake.

Scutellarin, one of the Traditional Chinese Medicines (TCM) used for liver diseases and diabetes, was found to reduce insulindependent lipid accumulation and the mRNA expression of CD36 in HepG2 cells-treated with palmitic acid (Luan et al., 2019). Several other TCM and isolated compounds, babaodan, licorice extract, polyphenol-enriched fraction from Herba Erigerontis, and magnesium lithospermate B, reduced hepatic CD36 expression in mice fed with High Fat Diet (HFD) (Wu and Wang, 2012; Wang et al., 2016; Sheng et al., 2019). Dansameum reduced the expression level of CD36 in liver of apolipoprotein E-Knockout mice with NAFLD (Ahn et al., 2019). In another mice model of NAFLD induced by high-fat and high-cholesterol diet, gypenosides which are a type of TCM extracted from plants downregulated CD36 level in the liver, alleviating the progression of hepatic steatosis (Huang et al., 2019). Berberine attenuated fat accumulation in the liver partially via suppressing the expression of FATP gene in HFD-fed mice (Zhou et al., 2019).

\section{Reducing Hepatic De Novo Lipogenesis}

De novo lipogenesis in the liver is tightly controlled by metabolic hormones such as insulin, and glucose level (Wang Y. et al., 2015). In the normal physiological status, high level of glucose promotes the secretion of insulin, activates carbohydrate-responsive elementbinding protein (ChREBP), and meanwhile, provides substrate to facilitate lipogenesis in the liver (Wang Y. et al., 2015). In terms of insulin, it activates sterol regulatory element-binding protein $1 \mathrm{c}$ (SREBP-1c) to up-regulate lipogenic enzymes, and then promotes de novo lipogenesis (Eissing et al., 2013; Chao et al., 2019). Figure 2 shows the overview of lipogenesis in hepatocytes. Herbs and isolated natural compounds have been demonstrated by animal studies and in vitro studies to alleviate hepatic steatosis by ChREBP pathway and insulin-SREBP-1c pathway, as well as other factors, such as AMPK, PPAR $\gamma$, SIRT1, inflammatory cytokines, immuno-modulation, and microRNAs. We summarized medicinal herbs and isolated natural compounds from recent literatures with the effects of reducing hepatic lipogenesis in Table 2 and discussed some representative studies in detail as following.

Magnolia officinalis Rehder \& E.H.Wilson, Houttuynia cordata Thunb., 3-Caffeoyl, 4-dihydrocaffeoylquinic acid from Salicornia europaea L., puerarin and four kinds metabolites of berberine attenuated lipid accumulation in HepG2 cells in vitro via downregulation of lipogenesis gene expressions through activation of the AMPK signaling pathway (Cao et al., 2013) (Pil Hwang et al., 2013; Kang and Koppula, 2014). Gyeongshingangjeehwan 18 (an herbal drug composed of Laminaria japonica, Rheum palmatum, and Ephedra sinica), Herbal Formula HT048 (Citrus unshiu and Crataegus pinnatifida), Fructus Xanthii (Xanthium sibiricum Patr.), Lycium barbarum polysaccharide, Jatrorrhizine hydrochloride, oxyresveratrol, and alisol A isolated from Rhizoma alismatis (Oriental Waterplantain Tuber.) attenuated liver steatosis in HFD-fed animals via regulating lipogenic genes, predominantly relating with downregulation of SREBP-1c expression via AMPK activation (Li et al., 2013; Li W. et al., 2014; Lee Y. H. et al., 2016; Yang et al., 2016; Lee et al., 2018; Lim et al., 2018; Ho et al., 2019). Gangjihwan, a polyherbal composition of Ephedra intermedia Schrenk \& C.A.Mey., Lithospermum erythrorhizon Siebold \& Zucc., and Rheum palmatum L., showed anti-obesity and antinonalcoholic steatohepatosis effects in HFD-fed mice. Lipogenic transcription factors, SREBP-1c, PPAR- $\gamma$, and ChREBP alpha were involved in the action mechanism (Jang et al., 2018); (Roh et al., 2017). Molecular targets of FAS, ACC1, ChREBP alpha, and SREBP-1c were also found to be involved in the underlying mechanism of anti-hepatic steatosis and anti-obesity-related hepatic inflammation effect of Gambigyeongsinhwan in Otsuka Long-Evans Tokushima fatty rats and HepG2 cells (Yoon et al., 2017).

Glycycoumarin, a representative of coumarin compounds isolated from licorice, and Alisol B 23-acetate exert ability of reducing hepatic lipogenesis in methionine-choline-deficient (MCD) diet-fed mice (Meng et al., 2017; Zhang E. et al., 2019). MCD diet is a classical dietary model of non-alcoholic steatohepatitis. With the lack of methionine and choline and high sucrose $(40 \%)$ and fat (10\%), impaired hepatic mitochondrial $\beta$ oxidation and very low-density lipoprotein (VLDL) synthesis are observed in mice (Ibrahim et al., 2016). Glycycoumarin activated AMPK signaling pathway to reduce lipogenesis. Alisol B 23acetate, a natural triterpenoid derived from TCM Rhizoma alismatis (Oriental Waterplantain Tuber.), decreased hepatic 


\begin{tabular}{|c|c|c|c|c|}
\hline Herbs or Natural products & Model & Effects & Mechanisms & References \\
\hline Rosmarinus officinalis Linn. & $\begin{array}{l}\text { Orotic acid } \\
\text { induced NAFLD } \\
\text { model in rats }\end{array}$ & $\begin{array}{l}\text { Reduced the levels of hepatic TG, } \\
\text { TC, FFA and improved cell } \\
\text { hypertrophy, vacuolation, and cell } \\
\text { necrosis in the liver }\end{array}$ & $\begin{array}{l}\uparrow \text { Phosphorylation of AMPK and } \downarrow \text { SREBP-1c cracking into the } \\
\text { nucleus, following } \downarrow \text { FAS }\end{array}$ & $\begin{array}{l}\text { (Wang et al., } \\
\text { 2019) }\end{array}$ \\
\hline Chinese Herbal Formula (CHF03, composition confidentiality) & $\begin{array}{l}\text { HFD induced } \\
\text { NAFLD model in } \\
\text { mice; AML12 } \\
\text { cells treated } \\
\text { with palmitic } \\
\text { acid in vitro }\end{array}$ & Reduced hepatic steatosis & $\begin{array}{l}\downarrow \text { lipogenesis via down-regulating the expression of SREBF1, Fasn, } \\
\text { and Acaca, } \downarrow \text { lipid accumulation }\end{array}$ & $\begin{array}{l}\text { (Cui et al., } \\
\text { 2019) }\end{array}$ \\
\hline $\begin{array}{l}\text { Dachaihu Decoction (Bupleuri Radix, Scutellaria baicalensis Georgi, Pinellia } \\
\text { ternate, Paeonia lactiflora, Citrus trifoliata, Rheum rhabarbarum, Zingiber } \\
\text { officinale, Ziziphus jujuba Mill) }\end{array}$ & $\begin{array}{l}\text { High-fat high- } \\
\text { fructose diet } \\
\text { induced NAFLD } \\
\text { model in rats }\end{array}$ & $\begin{array}{l}\text { Reduced the levels of elevated liver } \\
\text { coefficient, serum TG, TC, LDL, } \\
\text { AST, and ALT, blood glucose, } \\
\text { plasma endotoxin, reduced TG, } \\
\text { TNF- } \alpha \text {, TGF- } \beta \text {, NF-KB, and TLR4 } \\
\text { in liver tissues }\end{array}$ & $\downarrow$ oxidative stress and inflammation & $\begin{array}{l}\text { (Yang J.M. } \\
\text { et al., 2019) }\end{array}$ \\
\hline Leaves of Aloysia citrodora Paláu (syn. Lippia triphylla) & KK-Ay mice & Improved hepatic lipid metabolism & via activating AMPK & $\begin{array}{l}\text { (Zhang Y. } \\
\text { et al., 2019) }\end{array}$ \\
\hline Polygonatum kingianum & $\begin{array}{l}\text { HFD induced } \\
\text { NAFLD model in } \\
\text { rats }\end{array}$ & $\begin{array}{l}\downarrow A L T, A S T, T C, \text { LDL in serum, and } \\
\text { hepatic TC and TG }\end{array}$ & 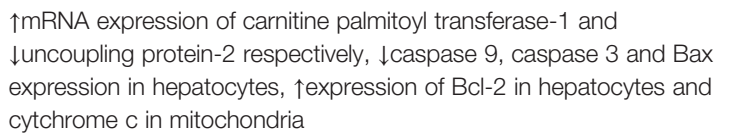 & $\begin{array}{l}\text { (Yang X.X. } \\
\text { et al., 2019) }\end{array}$ \\
\hline Bangpungtongseong-san (Bofutsushosan) & $\begin{array}{l}\text { HFD induced } \\
\text { NAFLD model in } \\
\text { C57BL/6J mice }\end{array}$ & $\begin{array}{l}\text { Ameliorated dyslipidemia and } \\
\text { hepatic steatosis, reduced body } \\
\text { weight gain }\end{array}$ & $\begin{array}{l}\text { Altered transcriptional changes in the liver, } \downarrow \text { mitochondrial oxidative } \\
\text { phosphorylation-related genes in the liver, } \downarrow \text { hepatic fibrosis-related } \\
\text { transcriptome. }\end{array}$ & $\begin{array}{l}\text { (Choi et al., } \\
\text { 2019) }\end{array}$ \\
\hline Thymbra spicata L. extracts & $\begin{array}{l}\text { endothelial cells } \\
\text { in vitro }\end{array}$ & $\begin{array}{l}\text { Ameliorated lipid accumulation, } \\
\text { oxidative stress and inflammation, } \\
\text { reduced hepatic steatosis }\end{array}$ & Preventing endothelium dysfunction & $\begin{array}{l}\text { (Khalil et al., } \\
\text { 2019) }\end{array}$ \\
\hline Swertiamarin & $\begin{array}{l}\text { fructose-fed } \\
\text { mice }\end{array}$ & $\begin{array}{l}\text { Lowed levels of serum glucose, } \\
\text { TG, uric acid, ALT, AST, alleviation } \\
\text { of hepatic ballooning degeneration } \\
\text { and steatosis }\end{array}$ & ISREBP-1, FAS and acetyl-CoA carboxylase 1 (ACC1) in liver & $\begin{array}{l}\text { (Yang Y. } \\
\text { et al., 2019) }\end{array}$ \\
\hline $\begin{array}{l}\text { Si He Decoction (Zingiber officinale., Cyperus rotundus L., Lilium, Lindera } \\
\text { aggregate, Salvia miltiorrhiza, Santalum album, Amomum villosum, Typha } \\
\text { angustifolia L., Trogopterus xanthipes Milne) }\end{array}$ & $\begin{array}{l}\text { HFD induced } \\
\text { NAFLD model in } \\
\text { rats }\end{array}$ & $\begin{array}{l}\text { Improved liver pathological } \\
\text { conditions }\end{array}$ & $\begin{array}{l}\text { Jexpression level of TNF-alpha and IL-6, †visfatin, adiponectin, leptin } \\
\text { and resistin, targeting adipokines }\end{array}$ & $\begin{array}{l}\text { (Sun et al., } \\
\text { 2019) }\end{array}$ \\
\hline $\begin{array}{l}\text { Modified Longdan Xiegan Tang (composed of Scutellaria baicalnsis Geprgi, } \\
\text { Gardenia jasminoides, Adenophora capillaris, Akebia quinate, Plantago } \\
\text { asiatica, Angelica sinensis, Rehmannia glutinosa, Alisma plantago-aquatica, } \\
\text { Bupleurum gibraltaicum, and Glycyrrhiza uralensis) }\end{array}$ & $\begin{array}{l}\text { Olanzapine- } \\
\text { induced fatty } \\
\text { liver in rats }\end{array}$ & $\begin{array}{l}\downarrow T G \text {, cell vacuolar degeneration } \\
\text { and Oil Red O-stained area }\end{array}$ & $\begin{array}{l}\text { Regulating hepatic de novo lipogenesis and fatty acid } \beta \text {-oxidation- } \\
\text { associated Gene expression mediated by SREBP-1c, PPAR- } \alpha \text { and } \\
\text { AMPK- } \alpha\end{array}$ & $\begin{array}{l}\text { (Ren et al., } \\
\text { 2019) }\end{array}$ \\
\hline LongShengZhi Capsule & $\begin{array}{l}\text { apoE-Deficient } \\
\text { Mice }\end{array}$ & Reduced atherosclerosis & $\begin{array}{l}\downarrow \text { lipogenic and cholesterol synthetic genes while activating expression } \\
\text { of triglyceride catabolism genes }\end{array}$ & $\begin{array}{l}\text { (Ma et al., } \\
\text { 2019) }\end{array}$ \\
\hline Thymoquinone & $\begin{array}{l}\text { Hypothyroidism } \\
\text { with NAFLD rats }\end{array}$ & $\begin{array}{l}\text { Reduced steatosis and lobular } \\
\text { inflammation }\end{array}$ & †antioxidant CAT gene & $\begin{array}{l}\text { (Ayuob } \\
\text { et al., 2019) }\end{array}$ \\
\hline Monomer Hairy Calycosin & NAFLD rats & $\begin{array}{l}\text { Control the lipid peroxidation, and } \\
\text { reduce the levels of serum TNF- } \\
\text { alpha, IL-6, MDA and FFA, improve } \\
\text { the steatosis and inflammation of liver } \\
\text { tissue }\end{array}$ & $\downarrow$ CYP2E1, $\downarrow$ apoptosis of hepatocytes. & $\begin{array}{l}\text { (Liu X. et al., } \\
\text { 2019) }\end{array}$ \\
\hline
\end{tabular}


Hongai Jiangzhi Formula (Astragali Radix, Red yeast rice, Nelumbinis Folium, Curcumae Longae Rhizoma, Lych Fructus, Magnoliae Officinals Cortex, Artemisiae Scopariae Herba)

Jiang Zhi Granule (Herba Gynostemmatis, Folium Nelumbinis, Radix

Salviae, Rhizoma Polygoni Cuspidati, and Herba Artemisiae Scopariae)

Curcumin

Samjunghwan Herbal Formula (Mori Fructus, Lycium chinensis Miller, Atractylodis Rhizoma)

Oxyresveratrol

Sedum sarmentosum Bunge extract

Berberine and curcumin

Gegen Qinlian decoction (Pueraria lacei Craib, Scutellaria baicalensis Georgi, Coptis chinensis Franch., and Glycyrrhiza uralensis Fisch.) and resveratrol

Gegenqinlian Decoction

Lingguizhugan Decoction (Poria, Ramulus Cinnamomi, Rhizoma Atractylodis Macrocephalae, and Radix Glycyrrhizae)

Chinese herb extract, QSHX (Bupleurum falcatum, Salvia miltiorrhiza rhubarb, lotus leaf, capillary Artemisia, rhizome polygoni cuspidate and gynostemma pentaphyllum)

Qushi Huayu Decoction (Herba Artemisiae capillaris, Polygonum cuspidatum, Hypericum japonicum Thunb, Gardenia, and Rhizoma Curcumae Longae)
HFD induced Reduced lipid accumulation NAFLD model in

rats

NAFLD in Showed anti-steatotic effects animal and PA-

treated

hepatocytes

in vitro

Steatotic

Improved lipid accumulation

model in vitro

and NAFLD rat

models

HepG2 Cells

and OLETF

$\downarrow$ Body weights, and visceral

adipose tissue (VAT) weights, AsT

Ameliorated NAFLD

Tilapia fatty liver Restored the changes to feed

model

coefficient, immune capacity, and pathological characters

HFD induced $\quad \downarrow L D L-C, A L T, A S T, A L P, M D A$, NAFLD model in LSP

rats

Rat model of Restored lipid metabolism and

HFD-induced inflammatory and histological

NAFLD

Rat model of

inflammatory and histologica
abnormalities

HFD-induced

regulate lipid

NAFLD and

HepG2

Rat model of Attenuated phenotypic

HFD-induced

characteristics of NAFLD

NAFLD

High-fat and $\quad \downarrow$ Body weight, liver index, and high-sugar diet- serum levels of AST, ALT and TG;

induced NAFLD and increased the serum level of

in rat

NAFLD rats adiponectin

Attenuated phenotypic

characteristics of NAFLD \the expression of NF-kappa B through TLR4 downstream signalling (Liang et al. pathways

2019)

droplet degradation via autophagy though the mTOR signalling

(Zheng

Reversed the DNA methylation at the PPAR-alpha gene

(LiY. Y.

et al., 2018)

$\uparrow H M G C O R$, SREBP, and ACC, and $\downarrow A M P K$ and LDLR gene

(Ansari

et al., 2018)

$\downarrow L X R$ alpha agonists-mediated SREBP-1c induction and expression of the lipogenic genes, $\uparrow m R N A$ of fatty acid beta-oxidation-related

(Lee et al., genes in hepatocytes; induced AMPK activation, helped inhibit

SREBP-1c using compound $\mathrm{C}$.

Altered expression of genes in the lipid metabolic process, metabolic (Huang

process, and oxidation-reduction process. Our results suggest that et al., 2018) disorders of the PPAR and p53 signaling pathways

$\downarrow$ SREBP-1c, pERK, TNF-alpha, and pJNK

(Feng et al., 2018)

Triggering the Sirt1 pathway

(Guo et al., 2017)

(Wang Y. L. et al., 2015)

By affecting insulin resistance and lipid metabolism related pathways (e.g., PI3K-Akt, AMPK); activating cholesterol secretio; increasing serum thyroid hormone levels, improving beta-oxidation (via

modulation of TR beta 1 and CPT1A expression), metabolism and transport (through modulation of SREBP-1c, ACSL and ApoB100 expression) of fatty acid.

Promoting the expression of HMW APN and DsbA-L, which may

have been induced by inhibiting the activation and expression of

FOXO1 in adipocytes

$\uparrow$ Hepatic anti-oxidative mechanism, \hepatic lipid synthesis, and promoted the regulatory $T$ cell inducing microbiota in the gut. 2017)

(Liu X. et al., 2017; Yang et al., 2017; Zhu et al.

2017)

(Liu X. et al., 2017) 
Herbal Formula HTO48 (Crataegus pinnatifida leaf and Citrus unshiu peel extracts.)

Angelica dahurica (Hoffm.) Benth. \& Hook.f. ex Franch. \& Sav.

Daisaikoto (Bupleuri Radix, Scutellaria baicalensis Georgi, Pinellia ternate, Paeonia lactiflora, Citrus trifoliata, Rheum rhabarbarum, Zingiber officinale, Ziziphus jujuba Mill)

Herb Formula KIOM2012H (Arctium lappa Linne, Glycyrrhiza uralensis Fischer, Magnolia officinalis Rehder \& Wilson, Zingiber officinale Roscoe) Hawthorn (Crataegus) leaf flavonoids

Herbal SGR Formula (Semen Hoveniae extract, Ginkgo biloba extract, and Rosa roxburghii Tratt extract)

Nitraria retusa (Forssk.) Asch. ethanolic extract

14-Deoxyandrographolide

Total Alkaloids in Rubus aleaefolius Poir

Lycium barbarum L. polysaccharide

Salacia oblonga Wall. ex Wight \& Arn. root

Chunggan extract (Artemisia capillaries Thunberg, Trionyx sinensis Wiegmann, Raphanus sativus Linne, tractylodes macrocephala Koidz, Poria cocos Wolf, Alisma orientalis (Sam.) Juzepczuk, Atractylodes

chinensis Koidzumi, Salvia miltiorrhiza Bunge, Polyporus umbellatus Fries, Poncirus trifoliate Rafin, Amomum villosum Lour, Glycyrrhiza uralensis Fisch., Aucklandia lappa Decne.)

Celastrus orbiculatus Thunb.

Oxymatrine
HepG2 cells and HFD-fed mice

Improves fatty liver syndrome

Attenuates Diet-Induced Obesity

$\downarrow T C$ and TG in the livers

HFD-induced

hyperlipidemic

mice

Diabetic fatty

liver rats

induced by a

high-fat diet and

streptozotocin

(STZ)

HFD-fed mice Inhibited lipid accumulation

HFD-fed rats

Acute ethanolinduced liver

steatosis in

mice

$\mathrm{db} / \mathrm{db}$ mice

model

Ethanol-induced

hepatosteatosis

in rats

Modified HFD-

fed rats

HFD-fed mice

fructose-

induced fatty

liver in rats

methionine- and $\quad \downarrow T G, A S T, A L T$, ALP, and total

choline-deficient bilirubin

(MCD) diet

HFD-induced

NAFLD in

guinea pigs

$\downarrow$ Body weight gain, liver weight,

fructose die

Reversing dyslipidemia and insulin resistance

\section{Alleviated NAFLD}

Inhibited acute ethanol-induced liver steatosis, $\downarrow$ serum and hepatic

imel, and improved classic

histopathological changes

$\downarrow$ Increases in body and fat mass weight, $\downarrow T G$ and LDL-c levels

eviate hepatosteatosis

ITG, TC, and LDL-C levels and $\uparrow H D L-C$ level

Improved body compositions and in metabolic profiles, \hepatic

intracellular TG

Diminished fructose-induced fatty liver
Increasing lipid oxidation and decreasing the lipogenesis pathway

iu Y. L.

et al., 2017)

$\downarrow$ Genes involved in lipogenesis, gluconeogenesis, and adipogenesis, (Lee Y. H. $\uparrow \beta$-oxidation genes

ICAT and sterol carrier protein2 (SCP2), $\uparrow$ the expression of lipid

metabolism related genes-lipase member C (LIPC) and PPAR- $\gamma \quad$ 2016)

Regulating expressions of SIRT1 and NF-kB

(Qian et al.,

2016)
Gene expressions involved in lipogenesis and related regulators

Enhancing the adiponectin/AMPK pathway

2015)

(Li et al.,

2015)

JProtein expression of hepatic SREBP-1c and TNF- $\alpha$ and increased (Qiu et al. adiponectin, PPAR- $\alpha$, and AMPK phosphorylation in the liver 2015)

$\uparrow$ Gene expression related to lipid homeostasis in liver, modulating the (Zar Kalai lipolysis-lipogenesis balance et al., 2014) $\uparrow A M P K$, ISREBP-1C, ACC, and FAS, $\uparrow$ sirtuin I and depletion of (Mandal malonyl-CoA, $\uparrow$ fatty acid oxidation

$\downarrow$ Expression of FAS, ACC, $\uparrow$ carnitine palmitoyltransferase (CPT)

SREBP-1C, $\uparrow$ AMPK activation

et al., 2014)

(Li Y. et al., 2014) (Li W. et al., 2014)

ISREBP-1/1c mRNA and nuclear protein

(Liu L. et al., 2013)

(Park et al., 2013)

†mRNA abundance of cholesterol 7 alpha-hydroxylase A1 (CYP7A1) (Zhang and 3-hydroxy-3-methyl-glutaryl-CoA reductase (HMGCR). et al., 2013)

$\downarrow$ SREBF1 and $\uparrow$ PPAR- $\alpha$ 


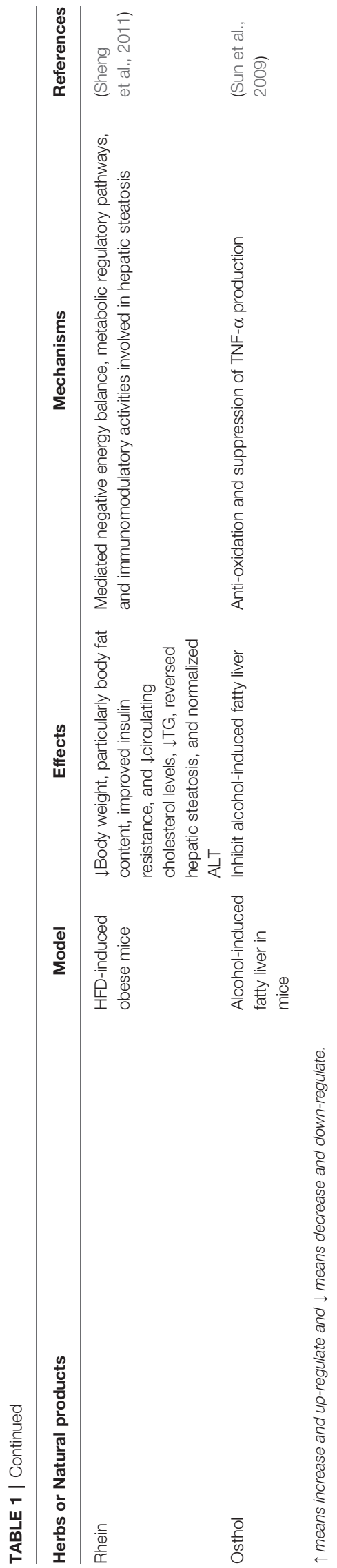

lipogenesis via FXR-dependent pathway. It decreased hepatic levels of SREBP-1c, FAS, ACC1 and SCD1, and promoted lipid metabolism via inducing PPAR $\alpha$, CPT1 $\alpha$, ACADS, and LPL (Meng et al., 2017). In an apolipoprotein E-knockout mice model, Dansameum (Salvia miltiorrhiza root), a kind of Korean polyherbal medicine, reduced hepatic lipogenesis, and inflammation via regulating PPAR- $\gamma$, SREBP-1c, FAS, ACC1, and CD36 (Ahn et al., 2019).

Dangguiliuhuang Decoction, a TCM formula composed of radix rehmanniae (root of Rehmannia Glutinosa), angelica (Angelica acutiloba Siebold et Zucc.), Coptis chinensis Franch., Radix Rehmanniae Praeparata (Rehmannia root), Astragalus propinquus (the root of astragalus membranaceus), Chinese skullcap (Scutellaria baicalensis) and Phellodendron amurense (Phellodendron chinense Schneid.), is used for the treatment of autoimmune diseases and diabetes (Cao et al., 2017; Cao et al., 2018). In a study of ob/ob mice model, it normalized glucose and insulin level, diminished fat accumulation and lipogenesis, increased the expression of adiponectin, and promoted glucose uptake (Cao et al., 2017). It showed modulation abilities on inflammation and immune response. Dangguiliuhuang Decoction (composition as listed above) promoted the shift of pro-inflammatory to anti-inflammatory cytokines. Furthermore, it decreased $\mathrm{T}$ cells proliferation while increased regulatory $\mathrm{T}$ cells (Tregs) differentiation, reduced dendritic cells (DCs) maturation and secretion of IL-12p70 cytokine, decreased DCs-stimulated $\mathrm{T}$ cells proliferation, and promoted, the interaction of DCs with Tregs. In adipocytes and hepatocytes as well as DCs and T cells, Dangguiliuhuang Decoction treatment altered PI3K/Akt signaling pathway and increased PPAR- $\gamma$ expression, indicating the ameliorated glucose and lipid metabolism (Cao et al., 2017).

MicroRNA (miR), a small non-coding RNA molecule, has been recently demonstrated to play a role in mediating the antihepatic steatosis effects of natural compounds derived from herbs. Berberine reduced steatosis in MIHA and HepG2 cells by mechanism associating with up-regulation of miR-373, which decreased its mRNA level target gene AKT serine/threonine kinase 1 (AKT1), resulting in the suppression of AKTmTOR-S6K signaling pathway in hepatocytes (Cao et al., 2018). Genipin reduced HFD-induced hyperlipidemia and hepatic lipid accumulation in mice via increasing the expression levels of miR-142a-5p, which bound to 3'untranslated region of SREBP-1c, thus leading to the inhibition of lipogenesis (Zhong et al., 2018).

\section{Increasing Lipolysis}

Lipolysis is the catabolic process of hydrolytic cleavage of ester bonds in TG, leading to the production of fatty acids and glycerol, which could be further utilized for $\beta$-oxidation and subsequent ATP generation (Lass et al., 2011). It predominantly occurs in adipose tissues, but also in the liver, with different physiological functions. Dietary fat is digested into the gut lymphatic system as chylomicrons, which arrives at the liver through the circulation and release NEFAs through lipolysis which mediated mainly by lipoprotein lipase (LPL) (Rui, 2014). Other lipolytic enzymes contributing to hepatic TG metabolism include adiponutrin/ 


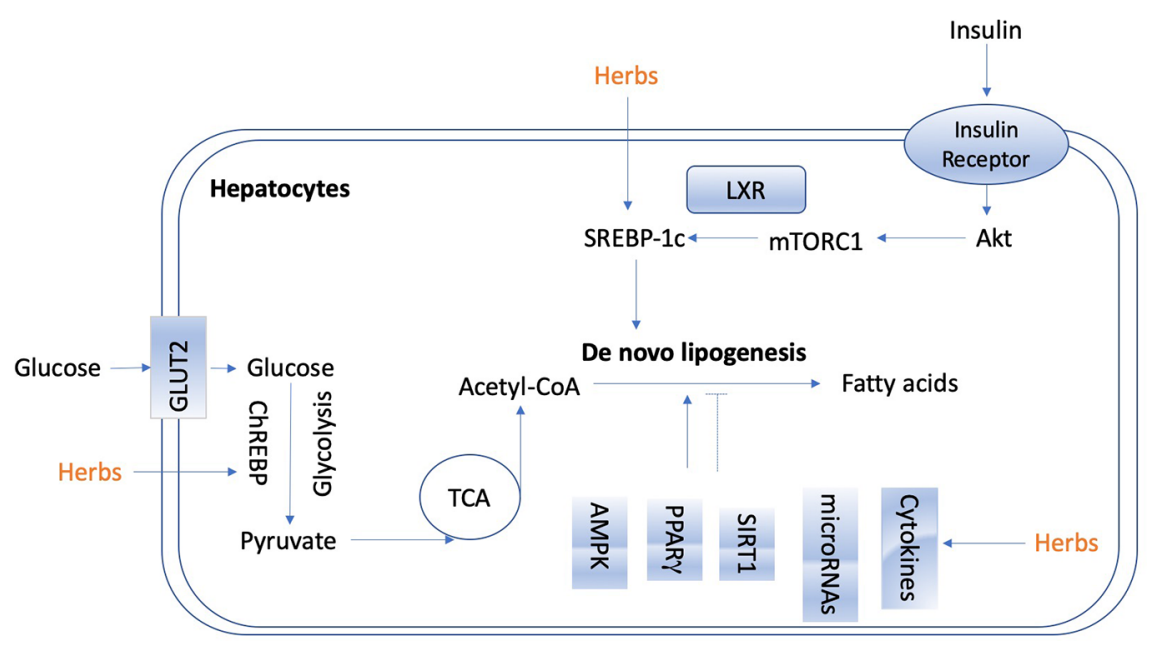

FIGURE 2 | The overview of lipogenesis in hepatocytes.

patatin-like phospholipase domain containing 3 (PNPLA3) (Kumashiro et al., 2013), lysosomal acid lipase (LAL) (Quiroga and Lehner, 2018), arylacetamide deacetylase (Lo et al., 2010), hepatic lipase (HL)(Chatterjee and Sparks, 2011) and some members of the carboxylesterase family. In adipose tissue, inhibition of lipolysis improves glucose metabolism and insulin sensitivity, whereas in liver tissue, increasing lipolysis facilitates the attenuation of hepatic steatosis.

As far from now, limited herbs were found to show regulatory effect on hepatic lipolysis. Lavatera critica (Cornish mallow), a green leafy vegetable, attenuated hepatic lipid accumulation induced by HFD via reversing lipolysis genes acetyl-CoA carboxylase (Veeramani et al., 2017). Nitraria retusa (Forssk.) Asch. ethanolic extract modulated the lipolysis-lipogenesis balance in the liver of $\mathrm{db} / \mathrm{db}$ mice (Veeramani et al., 2017). Caffeic acid upregulated the phosphorylation of AMPK and its primary downstream targeting enzyme, acetyl-CoA carboxylase, to promote the lipolysis in HepG2 cells with oleic acid administration (Liao et al., 2014). Polygonatum stenophyllum (PS) Maxim. rhizome showed efficacy on menopausal obesity by activating lipolysisrelated genes including hormone-sensitive lipase (HSL) and adipose triglyceride lipase (ATGL) (Lee J. E. et al., 2016). Mulberry (Fructus Mori) water extracts promoted hepatic lipolysis and protected liver from steatosis in obesity (Peng et al., 2011). More herbs or natural compounds exerted effects on lipolysis in adipose tissues and attenuated hepatic steatosis via liver-adipose tissue crosstalk, which are not going to be discussed in detail here.

\section{Induction of Lipophagy}

In addition to lipolysis, lipid breakdown can also be accessed via lipophagy, a special kind of autophagy to degrade lipid droplets (Singh and Cuervo, 2012; Kounakis et al., 2019). It is a process that the double membrane wraps lipid droplets and sends them to lysosomes to form autolysosomes for degradation of excessive lipid droplets deposited in cells (Liu and Czaja, 2013; Ward et al., 2016). It plays a vital role in maintaining the cellular steady state.
During the early stage of NAFLD, lipophagy is activated in response to acute increase in lipid availability, thus reduce lipid deposition (Czaja, 2016; Ipsen et al., 2018). However, in the condition of such as long-lasting high fat dieting, hepatic lipophagy is impaired when lipids are sustained overwhelmed (Kwanten et al., 2014; Czaja, 2016; Ipsen et al., 2018). Growing evidence raised from recent studies indicate that lipophagy is partially suppressed in patients and animal models of NAFLD and restoring lipophagy may slow the progression of hepatic steatosis. Lipophagy could be activated by various approaches, such as mTOR and AMPK-targeting agents. Glycycoumarin, a representative of coumarin compounds isolated from licorice, mitigated hepatic steatosis partially through AMPK-mediated lipophagy in a murine model of NAFLD induced by MCD diet (Zhang et al., 2016). Dioscin is a saponin extracted and isolated from Polygonatum zanlanscianense Pamp. It has been proposed as a healthcare product against hepatic fibrosis with remarkable ability to inhibit the expression of $\mathrm{p}-\mathrm{mTOR} / \mathrm{mTOR}$ level and sequentially promote autophagy (Xu et al., 2017). In another study, Bergamot polyphenol fraction prevents NAFLD via stimulation of lipophagy in cafeteria dietinduced rat model of metabolic syndrome. The increased levels of LC3 and Beclin 1, and concomitant reduction of SQSTM1/p62 proved the promoted lipophagy with the treatment of Bergamot polyphenol fraction (Parafati et al., 2015). Increasing number of herbs or natural products have been demonstrated to exert significant effects on regulating lipophagy in the liver. Current understanding of mechanisms associated with autophagy/ lipophagy of herbal medicines and natural products in preventing and treating NAFLD has been well reviewed in Zhang et al. (2018), which could be referred for further reading.

In alcoholic liver diseases (ALD), upon acute consumption of alcohol, lipophagy is activated in hepatocytes, serving as a defensive mechanism against injury to steatosis (Yan et al., 2019). However, it is impaired by chronic alcohol exposure, which is likely due to the activation of mTOR signaling and decreased lysosomal biogenesis in hepatocytes (Kounakis et al., 2019; Yang L. et al., 2019). There are 
TABLE 2 | Medicinal herbs and isolated natural compounds with the effect of hepatic lipogenesis reduction.

\begin{tabular}{|c|c|c|c|c|}
\hline Herbs or compounds & Model & Effect & Mechanism & References \\
\hline Dansameum (Salvia miltiorrhiza root) & $\begin{array}{l}\text { Apolipoprotein } \\
\text { E-Knockout } \\
\text { mice }\end{array}$ & $\begin{array}{l}\text { Reduced hepatic lipogenesis } \\
\text { and inflammation }\end{array}$ & $\begin{array}{l}\text { Regulating LXR- } \alpha \text {, PPAR- } \gamma \text {, SREBP-1, FAS, } \\
\text { ACC1, and CD36 }\end{array}$ & $\begin{array}{l}\text { (Ahn et al., } \\
\text { 2019) }\end{array}$ \\
\hline Alisol A & $\begin{array}{l}\text { HFD-induced } \\
\text { obese mice }\end{array}$ & $\begin{array}{l}\text { Reduced hepatic steatosis and } \\
\text { improved liver function }\end{array}$ & AMPK/ACC/SREBP-1c pathway & $\begin{array}{l}\text { (Ho et al., } \\
\text { 2019) }\end{array}$ \\
\hline $\begin{array}{l}\text { Ling-gui-zhu-gan decoction (Poria cocos, Ramulus } \\
\text { cinnamomi, Atractylodis macrocephalae Rhizoma } \\
\text { and Radix glycyrrhizae ) }\end{array}$ & HFD-fed rats & Reduced hepatic glycogen & $\begin{array}{l}\text { Inhibited the activity of ACC, SREBP-1C and } \\
\text { HMGCR, via inhibiting PPP1R3C targeting } \\
\text { pathways }\end{array}$ & $\begin{array}{l}\text { (Dang et al., } \\
\text { 2019) }\end{array}$ \\
\hline Salvianolic acids & $\begin{array}{l}\text { Ovariectomized } \\
\text { rats }\end{array}$ & $\begin{array}{l}\text { Reduced body weight gain and } \\
\text { attenuated }\end{array}$ & Blocking STAT-3/SREBP1 signaling & $\begin{array}{l}\text { (Dang et al., } \\
\text { 2019) }\end{array}$ \\
\hline $\begin{array}{l}\text { Gyeongshingangjeehwan } 18 \text { (Laminaria japonica, } \\
\text { Rheum palmatum, and Ephedra sinica) }\end{array}$ & $\begin{array}{l}\text { HFD-induced } \\
\text { obese mice }\end{array}$ & $\begin{array}{l}\text { Attenuated visceral obesity and } \\
\text { NAFLD }\end{array}$ & Down-regulated lipogenesis-related genes & $\begin{array}{l}\text { (Lim et al., } \\
\text { 2018) }\end{array}$ \\
\hline Cordycepin & $\begin{array}{l}\text { Oleic acid- } \\
\text { induced mouse } \\
\text { FL83B } \\
\text { hepatocytes }\end{array}$ & Attenuated lipid accumulation & $\begin{array}{l}\text { Activating AMPK and regulating mitochondrial } \\
\text { function }\end{array}$ & $\begin{array}{l}\text { (Uen et al., } \\
\text { 2018) }\end{array}$ \\
\hline Oxyresveratrol & HFD-fed mice & Ameliorated NAFLD & AMPK/SREBP-1c pathway & $\begin{array}{l}\text { (Lee et al., } \\
\text { 2018) }\end{array}$ \\
\hline Berberine & $\begin{array}{l}\text { MIHA and } \\
\text { HepG2 cells }\end{array}$ & Reduced hepatosteatosis & $\begin{array}{l}\text { Up-regulation of miR-373 decreased mRNA } \\
\text { level target gene AKT1, leading to inhibition of } \\
\text { AKT-mTOR-S6K signaling pathway in } \\
\text { hepatocytes }\end{array}$ & $\begin{array}{l}\text { (Li C. H. } \\
\text { et al., 2018) }\end{array}$ \\
\hline Genipin & HFD-fed mice & $\begin{array}{l}\text { Reduced HFD-induced } \\
\text { hyperlipidemia and hepatic lipid } \\
\text { accumulation }\end{array}$ & $\begin{array}{l}\text { Increased the expression levels of miR-142a- } \\
5 p \text {, which bound to } 3 \text { untranslated region of } \\
\text { SREBP-1c }\end{array}$ & $\begin{array}{l}\text { (Zhong } \\
\text { et al., 2018) }\end{array}$ \\
\hline $\begin{array}{l}\text { Gangjihwan (Ephedra intermedia Schrenk \& } \\
\text { C.A.Mey., Lithospermum erythrorhizon Siebold \& } \\
\text { Zucc., and Rheum palmatum L.) }\end{array}$ & $\begin{array}{l}\text { HFD-induced } \\
\text { obese mice }\end{array}$ & Inhibited fat accumulation & $\begin{array}{l}\text { Modulation of lipogenic transcription factors } \\
\text { SREBP-1c, PPAR- } \gamma \text { and ChREBP- } \alpha\end{array}$ & $\begin{array}{l}\text { (Jang et al., } \\
\text { 2018) }\end{array}$ \\
\hline $\begin{array}{l}\text { Gangjihwan (Ephedra intermedia Schrenk \& } \\
\text { C.A.Mey., Lithospermum erythrorhizon Siebold \& } \\
\text { Zucc., and Rheum palmatum L.) }\end{array}$ & $\begin{array}{l}\text { HFD-fed } \\
\text { C57BL/6 J } \\
\text { mice and } \\
\text { HepG2 cells }\end{array}$ & $\begin{array}{l}\text { Anti-obesity and anti- } \\
\text { nonalcoholic steatohepatosis }\end{array}$ & $\begin{array}{l}\text { Increased mRNA levels of fatty acid oxidation } \\
\text { genes and decreased mRNA levels of genes } \\
\text { for lipogenesis }\end{array}$ & $\begin{array}{l}\text { (Roh et al., } \\
\text { 2017) }\end{array}$ \\
\hline $\begin{array}{l}\text { Dangguiliuhuang Decoction (root of Rehmannia } \\
\text { Glutinosa, Angelica acutiloba Siebold et Zucc., } \\
\text { Coptis chinensis Franch., Radix Rehmanniae } \\
\text { Praeparata, Astragalus propinquus, Scutellaria } \\
\text { baicalensis, and Phellodendron chinense Schneid.) }\end{array}$ & ob/ob mice & $\begin{array}{l}\text { Normalized glucose and insulin } \\
\text { level, increased the expression of } \\
\text { adiponectin, diminished fat } \\
\text { accumulation and lipogenesis, } \\
\text { and promoted glucose uptake }\end{array}$ & $\begin{array}{l}\downarrow T \text { cells, } \uparrow \text { Tregs differentiation, } \downarrow \text { DCs } \\
\text { maturation, } \downarrow \text { DCs-stimulated T cells } \\
\text { proliferation and secretion of IL-12p70 } \\
\text { cytokine, promoted the interaction of DCs with } \\
\text { Tregs, changed PI3K/Akt signaling pathway } \\
\text { and } \uparrow \text { PPAR- } \gamma \text {. }\end{array}$ & $\begin{array}{l}\text { (Cao et al., } \\
\text { 2017) }\end{array}$ \\
\hline Glycycoumarin & MCD diet mice & Prevented hepatic steatosis & Activation of AMPK signaling pathway & $\begin{array}{l}\text { (Zhang } \\
\text { et al., 2016) }\end{array}$ \\
\hline $\begin{array}{l}\text { Gambigyeongsinhwan (Curcuma longa, Alnus } \\
\text { japonica, and Massa Medicata Fermentata) }\end{array}$ & $\begin{array}{l}\text { Otsuka Long- } \\
\text { Evans } \\
\text { Tokushima fatty } \\
\text { rats and HepG2 } \\
\text { cells }\end{array}$ & $\begin{array}{l}\text { Suppressed hepatic steatosis } \\
\text { and obesity-related hepatic } \\
\text { inflammation }\end{array}$ & $\begin{array}{l}\downarrow \text { mRNA levels of FAS, ACC1, ChREBP alpha, } \\
\text { and SREBP-1c }\end{array}$ & $\begin{array}{l}\text { (Yoon et al., } \\
\text { 2017) }\end{array}$ \\
\hline Alisol B 23-acetate & $\begin{array}{l}\text { MCD diet-fed } \\
\text { mice }\end{array}$ & $\downarrow A L T, A S T, T G$ & $\begin{array}{l}\text { FXR-dependent, thepatic lipogenesis through } \\
\text { decreasing hepatic levels of SREBP-1c, FAS, } \\
\text { ACC1 and SCD1 and } \uparrow \text { lipid metabolism via } \\
\text { inducing PPAR } \alpha, \text { CPT1 } \alpha, \text { ACADS and LPL }\end{array}$ & $\begin{array}{l}\text { (Meng et al., } \\
\text { 2017) }\end{array}$ \\
\hline $\begin{array}{l}\text { Herbal Formula HTO48 (Crataegus pinnatifida leaf } \\
\text { and Citrus unshiu peel extracts) }\end{array}$ & $\begin{array}{l}\text { HFD-fed obese } \\
\text { rats }\end{array}$ & $\begin{array}{l}\text { Decreased obesity and insulin } \\
\text { resistance }\end{array}$ & $\downarrow$ Genes involved in lipogenesis & $\begin{array}{l}\text { (Lee Y. H. } \\
\text { et al., 2016) }\end{array}$ \\
\hline Jatrorrhizine hydrochloride & $\begin{array}{l}\text { HFD-induced } \\
\text { obesity mouse } \\
\text { model }\end{array}$ & Attenuated hyperlipidemia & $\begin{array}{l}\downarrow \text { SREBP-1C and FAS, and induced PPAR- } \\
\text { and CPT1A }\end{array}$ & $\begin{array}{l}\text { (Yang et al., } \\
\text { 2016) }\end{array}$ \\
\hline Puerarin & $\begin{array}{l}\text { Oleic acid (OA)- } \\
\text { treated HepG2 } \\
\text { cells }\end{array}$ & Ameliorated hepatic steatosis & $\begin{array}{l}\uparrow P P A R-\alpha \text { and AMPK signaling pathways, } \\
\downarrow \text { SREBP- } 1 \text { and FAS expression }\end{array}$ & $\begin{array}{l}\text { (Kang et al., } \\
\text { 2015) }\end{array}$ \\
\hline Protopanaxatriol & $\begin{array}{l}\text { HFD-induced } \\
\text { obesity (DIO) } \\
\text { mice }\end{array}$ & Alleviated steatosis & Inhibition of PPAR- $\gamma$ activity & $\begin{array}{l}\text { (Zhang } \\
\text { et al., 2014) }\end{array}$ \\
\hline Magnolia officinalis Rehder \& E.H.Wilson & $\begin{array}{l}\text { HepG2 cells } \\
\text { and mouse }\end{array}$ & Attenuated TG biosynthesis & $\begin{array}{l}\text { Inhibition of SREBP-1c via AMPK } \\
\text { phosphorylation }\end{array}$ & $\begin{array}{l}\text { (Seo et al., } \\
\text { 2014) }\end{array}$ \\
\hline
\end{tabular}


TABLE 2 | Continued

\begin{tabular}{|c|c|c|c|c|}
\hline Herbs or compounds & Model & Effect & Mechanism & References \\
\hline & $\begin{array}{l}\text { normal FL83B } \\
\text { hepatocytes }\end{array}$ & & & \\
\hline Lycium barbarum polysaccharide & HFD-fed mice & Attenuate liver steatosis & \SREBP-1c expression via AMPK activation & $\begin{array}{l}(\text { Li W. et al., } \\
\text { 2014) }\end{array}$ \\
\hline Houttuynia cordata Thunb. & HepG2 & Attenuates Lipid Accumulation & AMPK signaling & $\begin{array}{l}\text { (Kang and } \\
\text { Koppula, } \\
\text { 2014) }\end{array}$ \\
\hline Berberine metabolites & HepG2 & TG-lowering effects & $\begin{array}{l}\downarrow \text { Lipogenesis gene expressions through } \\
\text { activation of the AMPK signaling pathway }\end{array}$ & $\begin{array}{l}\text { (Cao et al., } \\
\text { 2013) }\end{array}$ \\
\hline $\begin{array}{l}\text { 3-Caffeoyl, 4-dihydrocaffeoylquinic acid from } \\
\text { Salicornia herbacea Salicornia europaea L. }\end{array}$ & HepG2 & $\begin{array}{l}\text { Attenuated high glucose-induced } \\
\text { hepatic lipogenesis }\end{array}$ & $\begin{array}{l}\text { Prevented lipid accumulation by blocking the } \\
\text { expression of SREBP-1c and FAS through } \\
\text { LKB1/SIRT1 and AMPK activation }\end{array}$ & $\begin{array}{l}\text { (Pil Hwang } \\
\text { et al., 2013) }\end{array}$ \\
\hline Fructus Xanthii (Xanthium strumarium) & HFD-fed rats & Attenuated hepatic steatosis & $\downarrow$ The expression of lipogenic genes & $\begin{array}{l}\text { (Li et al., } \\
\text { 2013) }\end{array}$ \\
\hline
\end{tabular}

$\uparrow$ means increase and up-regulate and $\downarrow$ means decrease and down-regulate.

growing number of herbs and natural products have been found to protect liver from injury induced by alcohol by mechanism of lipophagy stimulation. Corosolic acid, a compound derived from the leaves of Langertroemia speciosa L Pers., protected the liver from alcoholic-induced liver injury partially via restoring hepatic lipophagy due to mTORC1 suppression after AMPK activation (Guo et al., 2016). Another natural compound, quercitin, which is extensively found in many fruits and herbal plants, remarkably reversed the alcohol-induced blockade of TFEB nuclear localization, via restoring lysosome function and autophagic flux in livers of ethanol-fed C57BL6 mice (Li et al., 2019). Salvianolic acid A, a phenolic carboxylic acid extracted from Salvia miltiorrhiza Bunge, reduced hepatic steatosis induced by alcohol administration in rats. The action mechanism is attributed to enhanced autophagosome-lysosome fusion after restoring lysosomal cathepsin activities (Shi et al., 2018).

As a matter of fact, the field of lipophagy in liver diseases has yet to be fully developed. Its pathological role in different stages and circumstances of various liver disorders still needs to be revealed. Nevertheless, current studies concerning lipophagy have already provided new insights on lipid metabolism and energy homeostasis in the liver. It represents a promising path forward to the therapeutic of hepatic steatosis. Pharmaceutic agents including herbs, natural products or compounds targeting lipophagy in the liver deserve to be further investigated in future basic and clinic researches.

\section{Enhancing Fatty Acid $\beta$-Oxidation}

Fatty acid could be oxidized by $\beta$-oxidation, $\alpha$-oxidation, omegaoxidation, and peroxisomal oxidation, among which $\beta$-oxidation is the major type occurring in the mitochondria matrix (Wanders et al., 2015). In $\beta$-oxidation, two carbon subunits from fatty acids are removed repeatedly until the fatty acid carbon chain is fully degraded to form acetyl-CoA, which is further oxidized to carbon dioxide and $\mathrm{H}_{2} \mathrm{O}$ in the tricarboxylic acid cycle (TCA) (Canbay et al., 2007). $\beta$ oxidation plays a vital role in hepatic lipid consumption. A variety of proteins and enzymes are involved in the process of mitochondrial fatty acid $\beta$-oxidation, such as plasma membrane fatty acid binding protein (FABPpm) (Furuhashi and Hotamisligil, 2008), fatty acid transport protein (FATP) (Ouali et al., 2000), carnitine acylcarnitine translocase (CACT) (Pierre et al., 2007), carnitine palmitoyltransferases
1 and 2 (CPT1/2), etc. (Bonnefont et al., 2004; Houten and Wanders, 2010). More importantly, mitochondrial fatty acid $\beta$-oxidation is regulated by both transcriptional and posttranscriptional mechanisms. Peroxisome proliferator-activated receptors (PPARs) are activated by fatty acids, having specific roles in physiology of different tissues (Yu et al., 2003; Lamichane et al., 2018). In liver, PPAR $\alpha$ controls many genes involved in mitochondrial fatty acid $\beta$-oxidation (Lamichane et al., 2018). In terms of posttranscriptional mechanism, the inhibition of CPT1 by malonyl-CoA is a vital regulatory step. The levels of malonyl-CoA in hepatocytes are regulated via degradation induced by malonyl-CoA decarboxylase and via production by acetyl-CoA carboxylase (ACC)(Park et al., 2002). PPARs-mediated activation persuades transcription of malonyl-CoA decarboxylase, and phosphorylated AMPK inactivated ACC (Saha and Ruderman, 2003). They stimulate mitochondrial fatty acid $\beta$-oxidation by reducing malonyl-CoA levels. Additionally, peroxisome proliferator activated receptor gamma coactivator 1-alpha (PGC$1 \alpha$ ) has also been regarded as a factor of posttranscriptional regulation of $\beta$-oxidation (Fernandez-Marcos and Auwerx, 2011). The activation of PGC- $1 \alpha$ is mediated by AMPK via SIRT1mediated deacetylation (Canto and Auwerx, 2009).

Many herbs and active compounds protect liver from steatosis via regulation of fatty acid $\beta$-oxidation. Herbacetin is a dietary flavonoid with plenty of pharmacological activities. Its antihyperglycemic and anti-hyperlipidemic properties was associated with up-regulation of CPT to enhanced $\beta$-oxidation and hepatic lipid metabolism (Veeramani et al., 2018). Acteoside, a major compound isolated from leaves of Aloysia citriodora Palau (syn. Lippia triphylla), promoted lipolysis and fatty acid oxidation by enhancing mRNA expression level of adipose triglyceride lipase (ATGL) and CPT-1, and thus improved hepatic lipid metabolism (Zhang Y. et al., 2019). Cordycepin enhanced $\beta$-oxidation and suppressed lipid accumulation via regulating AMPK pathway and mitochondrial fusion in hepatocytes (Uen et al., 2018).

In China, the modified Longdan Xiegan Tang (mLXT, composed of Scutellaria baicalnsis Geprgi, Gardenia jasminoides, Adenophora capillaris, Akebia quinate, Plantago asiatica, Angelica sinensis, Rehmannia glutinosa, Alisma plantago-aquatica, Bupleurum gibraltaicum, and Glycyrrhiza uralensis) has been used clinically for various liver diseases such as NAFLD. It was 
found to activate hepatic expression of PPAR $\alpha$ and its target genes associated with fatty acid $\beta$-oxidation (Ren et al., 2019). Babaodan, a TCM, up-regulated the expression of CPT- 1 and PPAR $\alpha$ in liver of HFD-fed mice with NAFLD, leading to the enhanced $\beta$-oxidation (Sheng et al., 2019). Rosa rugosa Thunb., another TCM, is used for treatment of cardiovascular diseases and diabetes, hypertension, hyperlipidemia, and inflammation. R. rugosa flavonoids, the major components in $\mathrm{R}$. rugosa Thunb., were observed to up-regulate the mRNA expression of PPAR $\alpha$ and its downstream gene of acylcoenzyme A oxidas $\mathrm{X}$ (ACOX) in a mouse model of hypertriglyceridemia (Baiyisaiti et al., 2019). Thereby, R. rugosa flavonoids could reduce TG in hepatocytes via rising $\beta$-oxidation. Gynura procumbens Merr., one of precious medicinal herbs of Asterceaes, up-regulated the mRNA expression of genes involved in $\beta$-oxidation, including PPAR $\alpha$, CPT1 $\alpha$, ACOX, fatty acid-binding proteins 5 (FABP5), stearoyl-coenzyme A desaturase-1 (SCD-1), glycerol-3-phosphate acyltransferase (mGPAT), microsomal triglyceride transfer protein (MTTP), to increase $\beta$-oxidation and efflux of fatty acids in liver of mice fed with MCD diet, and consequently decreased hepatic lipid accumulation (Liu Y. Y. et al., 2019). An herbal formula Gyeongshingangjeehwan 18 (GGEx18), composed of Laminaria japonica Aresch (Laminariaceae), Rheum palmatum L. (Polygonaceae) and Ephedra sinica Stapf (Ephedraceae), has traditionally been described to against obesity and related metabolic disease such as dyslipidemia. In HFD-fed mice receiving GGEx18, genes related to hepatic fatty acid $\beta$-oxidation was higher compared to mice fed with only HFD (Lim et al., 2018).

Evidence from recent studies has also indicated that some natural compounds promoted fatty acid oxidation by regulating the AMPK/PGC- $1 \alpha$ signaling pathway. Yellow pigments, monascin, and ankaflavin, as secondary metabolites derived from monascus-fermented products, could reduce fatty acid accumulation partly mediated by the AMPK signaling activation and enhancement of $\beta$-oxidation by PGC-1 $\alpha$ (Hsu et al., 2014). Myricetin, a natural flavonol with many biological activities, decreased PGC- $1 \alpha$ acetylation through SIRT1 activation, and thus enhanced mitochondrial activity, suggesting its potential role in regulating hepatic lipid metabolism (Jung et al., 2017).

\section{CLINICAL TRIALS}

Given to the encouraging effects of herbal medicines on liver diseases, plenty of clinical trials have been extensively performed. The potential therapeutic benefits of herbal medicines in patients with NAFLD have been reviewed in several papers in recent years (Xiao et al., 2013; Bedi et al., 2016; Perumpail et al., 2018). In present review, we focused on the efficacy of herbal medicines to mediate lipid metabolism and attenuate hepatic steatosis.

Dava Al-Balgham, as one of the traditional medicine products composed of Nigella sativa L., Pistacia lentiscus L., Zataria multiflora Boiss. (ZM), and Trachyspermum ammi, was tested for its effect on NAFLD by a randomized, double-blinded, placebocontrolled trial with 76 NAFLD patients. Placebo or Dava AlBalgham were consumed with each meal for three months. The results showed that Dava Al-Balgham could cause weight loss and have anti-hypolipidemic effect (Hormati et al., 2019).

The effect of $Z$. multiflora supplementation on NAFLD was studied by a randomized double-blind placebo-controlled clinical trial. Total 85 patients with NAFLD were treated with ZM powder (700 mg) or placebo twice daily for 3 months. However, no significant difference between two ZM-treated groups and placebo groups regarding ALT, TNF- $\alpha$, grade of fatty liver in ultrasonography, lipid profiles, and high sensitive C-reactive protein (hs-CRP), while it could improve insulin resistance in patients with NAFLD. Further studies with larger sample size and longer duration are recommended (Zamani et al., 2018).

A 12-weeks randomized, controlled, double-blind trial included with was 44 NAFLD patients, was performed to evaluate the efficacy of Capparis spinosa L. on disease regression of NAFLD. Patients are randomly divided into control $(n=22)$ or caper $(n=22)$ group. The caper group was treated with 40-50 g caper fruit pickles with meals every day. Results obtained after treatment of 12 weeks indicated that the grade of fatty liver and serum lipoproteins were improved by C. spinosa administration (Khavasi et al., 2017).

We further checked the registered clinical trials about testing effects of the herbs and natural products on fatty liver via the website of www.clinialtrial.gov. The intensively studied herbs and derived compounds are resveratrol, ginseng, and ginger, which were discussed in detail in following. Other herbs and some natural products that are undergoing or were performed clinical trials on fatty liver diseases are listed in Table 3.

Resveratrol is a stilbenoid and a phytoalexin generated by several plants, such as red grapes in response to stimuli (Hasan and Bae, 2017). It is an activator of AMPK and SIRT1, and thus has a critical role in promoting fat breakdown and removal from the liver, preventing liver damage and inhibiting the progression of NAFLD (Shang et al., 2008; Charytoniuk et al., 2017; Theodotou et al., 2019). Resveratrol has been involved in three trials (NCT01446276; NCT01464801; NCT02030977) included patients of fatty liver, NAFLD, and obesity.

Another herb, ginseng, has been traditionally used for more than 2,000 years with various biological effects. A great deal of preclinical studies have demonstrated the protective effects of ginseng on liver diseases, including ALD and NAFLD. Korean Red Ginseng (Panax ginseng) (Park et al., 2017) enhanced the decreased phosphorylation of AMPK induced by ethanol consumption. Notably, it reduced the accumulation of fat in hepatocytes caused by ethanol via regulation of SREBP-1, SIRT-1 and PPAR- $\alpha$ (Huu Tung et al., 2012; Park et al., 2017). Clinical trial (NCT0394512) has been performed to study the effect of red ginseng on liver dysfunction. Fermented ginseng powder has also been tested to study its efficacy on NAFLD (NCT03260543).

Ginger is the root of Zingiber officinale Roscoe and is one of the most used spices in many countries (Huu Tung et al., 2012). It contains active compounds, such as shogaol, gingerol, zingerone, and $\beta$-bisabolene. It has been shown that ginger can reduce insulin resistance and serum TG level in patients with Type II diabetes and hyperlipidemia (Arablou et al., 2014). In a randomized, double-blind, placebo-controlled clinical trial with 44 patients of NAFLD, ginger supplementation significantly 
TABLE 3 | Registered clinical trials of herbs and natural products on fatty liver diseases (Referred to http://www.ClinicalTrials.gov website).

\begin{tabular}{|c|c|c|c|c|c|c|}
\hline NCT number & Status & Conditions & Interventions & Outcome Measures & Population & Dates \\
\hline NCT02030977 & Completed & NAFLD & Resveratrol & ALT & $\begin{array}{l}\text { Enrollment: } 50 \\
\text { Age: } 18 \text { Years to } \\
80 \text { Years (Adult, } \\
\text { Older Adult) } \\
\text { Sex: All }\end{array}$ & $\begin{array}{l}\text { Study Start: June } 2012 \\
\text { Study Completion: March } 2013\end{array}$ \\
\hline NCT01464801 & Completed & Fatty liver & Resveratrol & $\begin{array}{l}\text { - Change in hepatic steatosis and inflammation } \\
\text { - Assessment of tolerability and side-effects }\end{array}$ & $\begin{array}{l}\text { Enrollment: } 28 \\
\text { Age: } 18 \text { Years to } \\
70 \text { Years (Adult, } \\
\text { Older Adult) } \\
\text { Sex: All }\end{array}$ & $\begin{array}{l}\text { Study Start: September } 2011 \\
\text { Study Completion: June } 2015\end{array}$ \\
\hline NCT01446276 & Completed & $\begin{array}{l}\text { Obesity } \\
\cdot \quad \text { NAFLD }\end{array}$ & Resveratrol & $\begin{array}{ll}\text { - } & \text { Hepatic VLDL-TG secretion and peripheral VLDL-TG clearance } \\
\text { - } & \text { Basal and insulin stimulated free fatty acid (FFA) and glucose turnover } \\
\text { - } & \text { VLDL-TG oxidation } \\
\text { - } & \text { Body composition (fat mass, fat-free mass, percent fat, visceral fat mass) } \\
\text { - } & \text { Baseline data }\end{array}$ & $\begin{array}{l}\text { Enrollment: } 26 \\
\text { Age: } 25 \text { Years to } \\
65 \text { Years (Adult, } \\
\text { Older Adult) } \\
\text { Sex: Male }\end{array}$ & $\begin{array}{l}\text { Study Start: November } 2011 \\
\text { Study Completion: April } 2014\end{array}$ \\
\hline NCT04130321 & $\begin{array}{l}\text { Not yet } \\
\text { recruiting }\end{array}$ & $\begin{array}{ll}\text { - } & \text { Overweight } \\
\text { - } & \text { Microtia } \\
\text { - } & \text { Endotoxemia } \\
\text { - } & \text { Metabolic } \\
& \text { Syndrome } \\
\text { - } & \text { Insulin Resistance } \\
\text { - } & \text { NAFLD }\end{array}$ & $\begin{array}{l}\text { Camu camu } \\
\text { (Myrciaria dubia) }\end{array}$ & 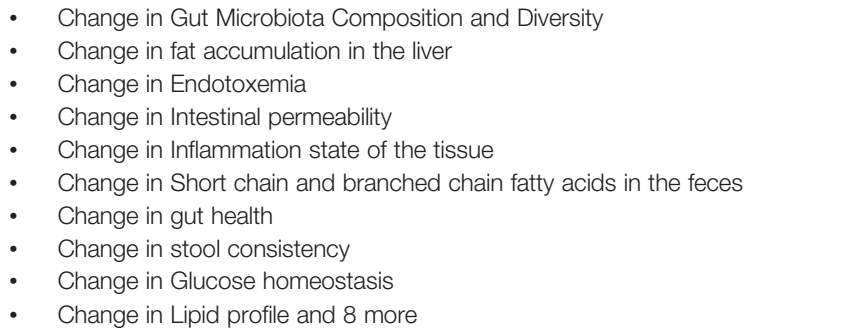 & $\begin{array}{l}\text { Enrollment: } 32 \\
\text { Age: } 18 \text { Years to } \\
75 \text { Years (Adult, } \\
\text { Older Adult) } \\
\text { Sex: All }\end{array}$ & $\begin{array}{l}\text { Study Start: January 6, } 2020 \\
\text { Study Completion: June 30, } 2022\end{array}$ \\
\hline NCT0394512 & Completed & Liver Dysfunction & Red ginseng & Liver enzyme & $\begin{array}{l}\text { Enrollment: } 94 \\
\text { Age: } 37 \text { Years to } \\
63 \text { Years (Adult) } \\
\text { Sex: All }\end{array}$ & $\begin{array}{l}\text { Study Start: January 1, } 2018 \\
\text { Study Completion: December 31, } 2018\end{array}$ \\
\hline NCT03260543 & Completed & NAFLD & $\begin{array}{l}\text { Fermented } \\
\text { ginseng powder }\end{array}$ & $\begin{array}{l}\text { Changes of ALT } \\
\cdot \quad \text { Changes of Liver function index } \\
\cdot \quad \text { Changes of fatty liver grade } \\
\cdot \quad \text { Changes of lipid metabolism index } \\
\cdot \quad \text { Changes of total antioxidant capacity } \\
\cdot \quad \text { Changes of imflammation index } \\
\end{array}$ & $\begin{array}{l}\text { Enrollment: } 90 \\
\text { Age: } 19 \text { Years to } \\
70 \text { Years (Adult, } \\
\text { Older Adult) } \\
\text { Sex: All }\end{array}$ & $\begin{array}{l}\text { Study Start: July } 2016 \\
\text { Study Completion: August } 2017\end{array}$ \\
\hline NCT04049396 & Completed & NAFLD & Berberine & $\begin{array}{l}\text { ALT; AST; ALP; fasting blood sugar; total cholesterol; LDL-Cholesterol; HDL - } \\
\text { Cholesterol; TG }\end{array}$ & $\begin{array}{l}\text { Enrollment: } 50 \\
\text { Age: } 18 \text { Years to } \\
65 \text { Years (Adult, } \\
\text { Older Adult) } \\
\text { Sex: All }\end{array}$ & $\begin{array}{l}\text { Study Start: October 1, } 2018 \\
\text { Study Completion: June 15, } 2019\end{array}$ \\
\hline NCT02535195 & Completed & NAFLD & Ginger & $\begin{array}{ll}\text { - } & \text { Serum levels of the ALT liver enzyme } \\
\text { - } & \text { Serum levels of the AST liver enzyme } \\
\text { - } & \text { controlled attenuation parameter(CAP) score }\end{array}$ & $\begin{array}{l}\text { Enrollment: } 60 \\
\text { Age: } 18 \text { Years to } \\
70 \text { Years (Adult, } \\
\text { Older Adult) } \\
\text { Sex: All }\end{array}$ & $\begin{array}{l}\text { Study Start: March } 2013 \\
\text { Study Completion: August } 2015\end{array}$ \\
\hline
\end{tabular}




\begin{tabular}{|c|c|c|c|c|c|c|}
\hline NCT number & Status & Conditions & Interventions & Outcome Measures & Population & Dates \\
\hline NCT02289235 & $\begin{array}{l}\text { Enrolling by } \\
\text { invitation }\end{array}$ & $\begin{array}{l}\text { - } \text { Fatty Liver } \\
\text { Diabetes Mellitus, } \\
\text { Type } 2\end{array}$ & Ginger & $\begin{array}{ll}\text { - } & \text { Change in ALT level } \\
\text { - } & \text { Change in AST level } \\
\text { - } & \text { Change in score of fatty liver in fibroscan } \\
\text { - } & \text { Change in Gama GT (\#- glutamyl transpeptidase) levels } \\
& \text { Number of patients with adverse events }\end{array}$ & $\begin{array}{l}\text { Enrollment: } 90 \\
\text { Age: } 20 \text { Years to } \\
65 \text { Years (Adult, } \\
\text { Older Adult) } \\
\text { Sex: All }\end{array}$ & $\begin{array}{l}\text { Study Start: November 1, } 2018 \\
\text { Study Completion: December 1, } \\
2019\end{array}$ \\
\hline NCT03864783 & Recruiting & $\begin{array}{ll}\text { - } & \text { NAFLD } \\
\text { - } & \text { Insulin Resistance } \\
\text { Glucose } \\
\text { Tolerance } \\
\text { Impaired } \\
\text { - Obesity, } \\
\text { Abdominal }\end{array}$ & $\begin{array}{l}\text { Curcumin } \\
\left(\text { Meriva }^{\circledR}\right)\end{array}$ & $\begin{array}{l}\text { - Curcumin's effect on steatosis } \\
\text { - } \quad \text { Total amino acids in plasma } \\
\text { - } \quad \text { Cotal amino acids in plasma } \\
\text { - Curcumin's effect on plasma concentration of urea } \\
\text { - } \quad \text { Curcumin's effect on urin concentration of urea } \\
\text { - Curcumin's effect on serum concentration of inflammatory marker interleukin (IL)-1b } \\
\text { - Curcumin's effect on serum concentration of inflammatory marker IL-2 } \\
\text { - Curcumin's effect on serum concentration of inflammatory marker IL-10 } \\
\text { - Curcumin's effect on serumconcentration of inflammatory marker tumor } \\
\text { - } \quad \text { Curcumin's effect on plasma concentration of adipokines } \\
\text { and } 34 \text { more }\end{array}$ & $\begin{array}{l}\text { Enrollment: } 40 \\
\text { Age: } 20 \text { Years and } \\
\text { older (Adult, Older } \\
\text { Adult) Sex: Male }\end{array}$ & $\begin{array}{l}\text { Study Start: March 5, } 2019 \\
\text { Study Completion: October } 2020\end{array}$ \\
\hline NCT03073343 & Recruiting & $\begin{array}{l}\text { Non-Alcoholic Fatty } \\
\text { Liver Disease } \\
\text { - Non Insulin } \\
\text { Dependent } \\
\text { Diabetes } \\
\text { - ALT }\end{array}$ & Betaine & ALT & $\begin{array}{l}\text { Enrollment: } 48 \\
\text { Age: } 18 \text { Years to } \\
75 \text { Years (Adult, } \\
\text { Older Adult) } \\
\text { Sex: All }\end{array}$ & $\begin{array}{l}\text { Study Start: November 12, } 2013 \\
\text { Study Completion: June 30, } 2020\end{array}$ \\
\hline NCT02973295 & Recruiting & NAFLD & Silymarin & $\begin{array}{l}\text { - } \quad \text { Change (Reduction) } \\
\text { of parameters of liver steatosis defined by CAP (Controlled Attenuation } \\
\text { - } \quad \text { Parameter) and liver fibrosis defined by } \\
\text { - } \quad \text { Changer in liver enzymes in pents) during the } 6 \text { months period } 6 \text { months } \\
\text { - } \quad \text { Change in insulin resistance in period of } 6 \text { months } \\
\text { - } \quad \text { Change in lipidogram in period of } 6 \text { months }\end{array}$ & $\begin{array}{l}\text { Enrollment: } 400 \\
\text { Age: } 18 \text { Years to } \\
70 \text { Years (Adult, } \\
\text { Older Adult) } \\
\text { Sex: All }\end{array}$ & $\begin{array}{l}\text { Study Start: September 20, } 2019 \\
\text { Study Completion: June 30, } 2021\end{array}$ \\
\hline NCT02929901 & Completed & $\begin{array}{l}\text { Type } 2 \text { Diabetes } \\
\text { Nonalcoholic Fatty } \\
\text { Liver }\end{array}$ & $\begin{array}{l}\text { Caffeine and } \\
\text { chlorogenic acid }\end{array}$ & $\begin{array}{ll}\text { - } & \text { Hepatic steatosis } \\
\text { - } & \text { Glucose } \\
\text { - } & \text { Glycated hemoglobin (HBA1C) } \\
\text { - } & \text { ALT } \\
\text { : } & \text { AST } \\
\text { : } & \text { hs- CRP) } \\
\text { - } & \text { gut microbiota }\end{array}$ & $\begin{array}{l}\text { Enrollment: } 200 \\
\text { Age: } 30 \text { Years to } \\
65 \text { Years (Adult, } \\
\text { Older Adult) } \\
\text { Sex: All }\end{array}$ & $\begin{array}{l}\text { Study Start: December } 2016 \\
\text { Study Completion: March } 2019\end{array}$ \\
\hline NCT02908152 & $\begin{array}{l}\text { Unknown } \\
\text { status }\end{array}$ & $\begin{array}{l}\text { - } \quad \text { Type } 2 \text { Diabetes } \\
\text { - } \\
\text { Nonalcoholic Fatty } \\
\text { Liver }\end{array}$ & Curcumin & $\begin{array}{ll}\cdot & \text { Hepatic steatosis } \\
\text { - } & \text { Glucose } \\
\text { - } & \text { HBA1C } \\
\text { - } & \text { ALT } \\
\text { - } & \text { AST }\end{array}$ & $\begin{array}{l}\text { Enrollment: } 50 \\
\text { Age: } 30 \text { Years to } \\
65 \text { Years (Adult, } \\
\text { Older Adult) } \\
\text { Sex: All }\end{array}$ & $\begin{array}{l}\text { Study Start: February } 2017 \\
\text { Study Completion: October } 2017\end{array}$ \\
\hline NCT02006498 & Completed & NAFLD & Sillymarin & $\begin{array}{l}\text { - To assess the efficacy } \\
\text { - of Silymarin as defined by an improvement in non-alcoholic steatosis (NAS) } \\
\text { activity score by at least } 30 \% \text { from baseline compared to placebo } \\
\text { - To assess the safety and adverse event profile of Silymarin compared to placebo }\end{array}$ & $\begin{array}{l}\text { Enrollment: } 99 \\
\text { Age: } 18 \text { Years and } \\
\text { older (Adult, Older } \\
\text { Adult) } \\
\text { Sex: All }\end{array}$ & $\begin{array}{l}\text { Study Start: June } 2012 \\
\text { Study Completion: December } 2015\end{array}$ \\
\hline
\end{tabular}

\section{Dependent}

Diabetes

$\mathrm{AL}$

NCT02973295 Recruiting NAFLD

Change (Reduction)

of parameters of liver steatosis defined by CAP (Controlled Attenuation Parameter) and liver fibrosis defined by

Change in liver enzymes in period of 6 month

- Glycated hemoglobin (HBA1C)

- AST

- hs- CRP

gut microbiota

Hepatic steatosis

- HBA1C

ALT

To assess the efficacy

activity score by at least $30 \%$ from baseline compared to placebo

Sex: All 


\begin{tabular}{|c|c|c|c|c|c|c|}
\hline NCT number & Status & Conditions & Interventions & Outcome Measures & Population & Dates \\
\hline NCT01940263 & Completed & NAFLD & Anthocyanin & $\begin{array}{ll}\text { - } & \text { Biomarkers related to oxidative stress } \\
\text { - } & \text { Biomarkers related to inflammation }\end{array}$ & $\begin{array}{l}\text { Enrollment: } 63 \\
\text { Age: } 18 \text { Years to } \\
65 \text { Years (Adult, } \\
\text { Older Adult) } \\
\text { Sex: All }\end{array}$ & $\begin{array}{l}\text { Study Start: June } 2013 \\
\text { Study Completion: June } 2014\end{array}$ \\
\hline NCT02307344 & $\begin{array}{l}\text { Unknown } \\
\text { status }\end{array}$ & $\begin{array}{l}\text { - } \quad \text { Nonalcoholic } \\
\text { - } \quad \text { Lteatohepatitis } \\
\text { Liver Steatosis }\end{array}$ & Nigella sativa L. & $\begin{array}{ll}\text { - } & \text { Effect of Nigella Sativa on Liver Triglyceride Concentration } \\
\text { - } & \text { Effect of Nigella Sativa on Improvement in NASH Activity Index } \\
\text { - } & \text { Effect of Nigella Sativa on Fibrosis Staging }\end{array}$ & $\begin{array}{l}\text { Enrollment: } 100 \\
\text { Age: } 18 \text { Years and } \\
\text { older (Adult, Older } \\
\text { Adult) } \\
\text { Sex: All }\end{array}$ & $\begin{array}{l}\text { Study Start: January } 2015 \\
\text { Study Completion: January } 2017\end{array}$ \\
\hline NCT02303314 & Completed & NAFLD & $\begin{array}{l}\text { Trigonella } \\
\text { Foenum- } \\
\text { graecum Seed } \\
\text { Extract }\end{array}$ & Liver stiffness change & $\begin{array}{l}\text { Enrollment: } 35 \\
\text { Age: } 18 \text { Years to } \\
70 \text { Years (Adult, } \\
\text { Older Adult) } \\
\text { Sex: All }\end{array}$ & $\begin{array}{l}\text { Study Start: November } 2014 \\
\text { Study Completion: September } 2017\end{array}$ \\
\hline NCT01707914 & Completed & NAFLD & $\begin{array}{l}\text { Chinese } \\
\text { bayberry juice } \\
\text { (Myrica rubra) }\end{array}$ & Plasma lipids profile & $\begin{array}{l}\text { Enrollment: } 44 \\
\text { Age: } 18 \text { Years to } \\
25 \text { Years (Adult) } \\
\text { Sex: All }\end{array}$ & Study Start: June 2012 \\
\hline NCT01677325 & Completed & NAFLD & $\begin{array}{l}\text { Drug: Chinese } \\
\text { herb (YiQiSanJu) } \\
\text { (Angelica } \\
\text { sinensis, } \\
\text { Rehmannia, } \\
\text { Cinnamomum } \\
\text { cassia, } \\
\text { Glycyrhiza } \\
\text { uralensis, } \\
\text { Eucommia } \\
\text { ulmoides, } \\
\text { Achyranthes } \\
\text { bidentate, } \\
\text { Lycium } \\
\text { chinense) }\end{array}$ & $\begin{array}{ll}\text { - } & \text { The CT ratio of liver/spleen } \\
\text { : } & \text { BMI(Body Mass Index) } \\
\text { - } & \text { liver function } \\
\text { - } & \text { lipid profile } \\
\text { : } & \text { NEFA } \\
\text { : } & \text { HOMA index } \\
\text { : } & \text { adiponectin } \\
\text { : } & \text { IL-6 } \\
\text { - } & \text { hs-CRP (C-reactive protein) } \\
\text { - } & \text { TNF-a } \\
\text { - } & \text { leptin }\end{array}$ & $\begin{array}{l}\text { Enrollment: } 40 \\
\text { Age: } 18 \text { Years to } \\
65 \text { Years (Adult, } \\
\text { Older Adult) Sex: } \\
\text { Male }\end{array}$ & $\begin{array}{l}\text { Study Start: January } 2007 \\
\text { Study Completion: January } 2008\end{array}$ \\
\hline NCT01210989 & Completed & NAFLD & $\begin{array}{l}\text { Phyllanthus } \\
\text { urinaria L. }\end{array}$ & $\begin{array}{ll}\text { - } & \text { Histologic NAFLD activity score } \\
\text { - } & \text { ALT normalization } \\
\text { - } & \text { Metabolic endpoints } \\
\text { - } & \text { Changes in magnetic resonance spectroscopy } \\
\text { - } & \text { Liver stiffness measurement } \\
\text { Biomarkers of NASH and liver fibrosis }\end{array}$ & $\begin{array}{l}\text { Enrollment: } 60 \\
\text { Age: } 18 \text { Years to } \\
70 \text { Years (Adult, } \\
\text { Older Adult) } \\
\text { Sex: All }\end{array}$ & $\begin{array}{l}\text { Study Start: May } 2010 \\
\text { Study Completion: May } 2012\end{array}$ \\
\hline NCT00816465 & Completed & NAFLD & $\begin{array}{l}\text { Hoodia gordonii } \\
\text { (Masson) Sweet } \\
\text { ex Decne. }\end{array}$ & $\begin{array}{ll}\text { - } & \text { Decreased insulin resistance } \\
\text { - } & \text { Safety } \\
\text { - } & \text { Reduced hepatic injury } \\
\text { - } & \text { Reduced weight/BMl/abdominal circumference }\end{array}$ & $\begin{array}{l}\text { Enrollment: } 20 \\
\text { Age: } 18 \text { Years to } \\
65 \text { Years (Adult, } \\
\text { Older Adult) } \\
\text { Sex: All }\end{array}$ & $\begin{array}{l}\text { Study Start: May } 2009 \\
\text { Study Completion: August } 2010\end{array}$ \\
\hline
\end{tabular}


reduced the levels of ALT, inflammatory cytokines, $\gamma$-glutamyl transferase, as well as hepatic steatosis grade and the insulin resistance index in comparison to the control group. Another clinical trial of ginger supplement on fatty liver or Type 2 Diabetes Mellitus is still undergoing (NCT02289235).

\section{META-ANALYSIS STUDIES}

HuoXueHuaYu (HXHY), a TCM formula, has been widely used in clinic for patients with NAFLD. Cai et al. performed a meta-analysis of randomized controlled trial of HXHY in NAFLD. There are 13 studies involving 1429 patients which 654 patients receiving conventional treatment group and 775 patients belonged to HXHY group. HXHY showed better ability on lowing TC and TG levels than that of conversational treatment. HXHY might be an effective and safe therapy for NAFLD, and trials with rigorous design, multicenter, large-scale, and high-quality worldwide are still expected (Cai et al., 2019).

Erchen Decoction (ECD), a TCM formula, is often used in the therapy of various diseases. A meta-analysis of the efficacy of ECD for the treatment of NAFLD by PRISMA systematic review standard has been performed. Seven randomized controlled trial with a total of 1951 participants were included in this study. The analysis results showed that patients with ECD treatment showed an improved status compared to the conventional treatment. Longer follow-up periods and larger-scale randomized controlled trial are still required to evaluate the efficacy of ECD in NAFLD (Li et al., 2017).

The efficiency and safety of a famous TCM Danshen in the treatment of NAFLD has also been analyzed by a meta-analysis study. Eight randomized controlled trials with 800 patients of NAFLD were identified. The results indicated that Danshen had improved total effectiveness rate, lower level of TC, TG, LDL, ALT, and AST, suggesting that Danshen may have potential effects on NAFLD, while multicenter large-sample randomized clinical trials are still expected to confirm the efficacy and safety of Danshen (Peng et al., 2016).

Another study performed by Narjes et al. on 2017 has evaluated the efficiency of all kinds of TCM on the treatment of NAFLD. Literature were searched on China National Knowledge and PubMed from 1995 to 2010. Total 5904 patients from 62 randomized controlled trials were included for meta-analysis. Results showed that TCM had a better effect on the normalization of ALT level and disappearance of radiological steatosis for the patients of NAFLD. Finally, authors concluded that TCM is of modest benefit to the therapy of NAFLD (Shi et al., 2012).

\section{CONCLUSIONS AND PERSPECTIVES}

Due to the positive efficacy and minimal side effects, herbal medicines have obtained increasing attention as alternative therapeutic agents for liver disorders and dyslipidemia. Increasing evidence from laboratory studies suggests that many herbs, natural products, and derived compounds could inhibit the progression of hepatic steatosis. A variety of mechanisms have been demonstrated to be implicated in preventing hepatic steatosis and modulating lipid metabolism by herbs, including reducing hepatocyte fatty acid uptake and trafficking, reducing hepatic de novo lipogenesis, increasing lipolysis, inducing lipophagy, enhancing fatty acid $\beta$ oxidation. In particular, SREBP-1c, PPAR $\alpha$, AMPK, and SIRT1 signaling pathways have been highlighted as crucial molecular targets of action mechanisms by which herbal medicines regulate hepatic lipid metabolism. Current clinical evidences and metaanalysis showing the positive impacts of herbal medicines on the hepatic lipid metabolism pathways are still not strong enough. Further multicenter large-sample randomized clinical trials are still required to confirm the efficacy and safety of herbal medicines on hepatic lipid metabolism. Herbs mix and single medical plants as well as their components have been widely applied in the treatment of NAFLD. We consider the main actor should be the active components. For both herbs mix and single medical plants, they are containing many compounds, which may act synergistically in ways to enhance the therapeutic effects. Identifying the active components in herbs is a crucial and significant subject for the development of TCM. Currently, network pharmacology-based strategy has been extensively used for the prediction of the active components from herbs. Network pharmacology is an approach based on systems biology, poly-pharmacology, and molecular networks, to analyze relationships between drugs and diseases in recent decade, which has attracted considerable attention among Chinese medicine researchers for its ability in predicting and illustrating interactive relationships between numerous components and targets of herbal medicines. Network-based pharmacological analysis is a desirable approach as well as a good tool of in silico prediction for investigating the mechanisms of action for herbs and formulae and their potential bioactive components at molecular and systematic levels, which renders more effective subsequent exploration with experimental approaches. With the promising and effective prediction, subsequently validation experiments in laboratory and bench would be performed to confirm their pivotal role. In conclusion, herbal medicines have the potency to be alternative and complementary medical therapies to current pharmaceuticals for the treatment of liver diseases with lipid metabolism disorder.

\section{AUTHOR CONTRIBUTIONS}

YF designed and conceived the study. SL and YF retrieved and analyzed the data, and drafted the manuscript. SL, YX, WG, FC, CZ, HT, and NW discussed and revised the manuscript. All authors confirmed final version of the manuscript.

\section{FUNDING}

This research was partially supported by the Research Council of the University of Hong Kong (project codes: 104004092 and 104004460), Wong's donation (project code: 200006276), a donation from the Gaia Family Trust of New Zealand (project code: 200007008), the Research Grants Committee (RGC) of Hong Kong, HKSAR (project codes: 740608, 766211, 17152116, and 17121419), and Health and Medical Research Fund (project codes: 15162961, 16171511, and 16172751). 


\section{REFERENCES}

Ahn, S. H., Lee, K. P., Kim, K., Choi, J. Y., Park, S. Y., and Cheon, J. H. (2019). Dansameum regulates hepatic lipogenesis and inflammation in vitro and in vivo. Food Sci. Biotechnol. 28 (5), 1543-1551. doi: 10.1007/s10068-019-00579-8

Albhaisi, S., and Sanyal, A. (2018). Recent advances in understanding and managing non-alcoholic fatty liver disease. F1000Res 7. doi: 10.12688/ f1000research.14421.1

Al-Dayyat, H. M., Rayyan, Y. M., and Tayyem, R. F. (2018). Non-alcoholic fatty liver disease and associated dietary and lifestyle risk factors. Diabetes Metab. Syndr. 12 (4), 569-575. doi: 10.1016/j.dsx.2018.03.016

Ansari, A., Bose, S., Patra, J. K., Shin, N. R., Lim, D. W., Kim, K. W., et al. (2018). A Controlled Fermented Samjunghwan Herbal Formula Ameliorates Nonalcoholic Hepatosteatosis in HepG2 Cells and OLETF Rats. Front. Pharmacol. 9, 596. doi: 10.3389/fphar.2018.00596

Arablou, T., Aryaeian, N., Valizadeh, M., Sharifi, F., Hosseini, A., and Djalali, M. (2014). The effect of ginger consumption on glycemic status, lipid profile and some inflammatory markers in patients with type 2 diabetes mellitus. Int. J. Food Sci. Nutr. 65 (4), 515-520. doi: 10.3109/09637486.2014.880671

Aronow, W. S. (2006). Management of hyperlipidemia with statins in the older patient. Clin. Interv. Aging 1 (4), 433-438. doi: 10.2147/ciia.2006.1.4.433

Ayuob, N. N., Abdel-Hamid, A., Helal, G. M. M., and Mubarak, W. A. (2019). Thymoquinone reverses nonalcoholic fatty liver disease (NAFLD) associated with experimental hypothyroidism. Rom. J. Morphol. Embryol. 60 (2), 479-486.

Baiyisaiti, A., Wang, Y., Zhang, X., Chen, W., and Qi, R. (2019). Rosa rugosa flavonoids exhibited PPARalpha agonist-like effects on genetic severe hypertriglyceridemia of mice. J. Ethnopharmacol. 240, 111952. doi: 10.1016/j.jep.2019.111952

Bedi, O., Bijjem, K. R. V., Kumar, P., and Gauttam, V. (2016). Herbal Induced Hepatoprotection and Hepatotoxicity: A Critical Review. Indian J. Physiol. Pharmacol. 60 (1), 6-21.

Bonnefont, J. P., Djouadi, F., Prip-Buus, C., Gobin, S., Munnich, A., and Bastin, J. (2004). Carnitine palmitoyltransferases 1 and 2: biochemical, molecular and medical aspects. Mol. Aspects Med. 25 (5-6), 495-520. doi: 10.1016/ j.mam.2004.06.004

Cai, Y., Liang, Q., Chen, W., Chen, M., Chen, R., Zhang, Y., et al. (2019). Evaluation of HuoXueHuaYu therapy for nonalcoholic fatty liver disease: a systematic review and meta-analysis of randomized controlled trial. BMC Complement Altern. Med. 19 (1), 178. doi: 10.1186/s12906-019-2596-3

Canbay, A., Bechmann, L., and Gerken, G. (2007). Lipid metabolism in the liver. $Z$. Gastroenterol. 45 (1), 35-41. doi: 10.1055/s-2006-927368

Canto, C., and Auwerx, J. (2009). PGC-1alpha, SIRT1 and AMPK, an energy sensing network that controls energy expenditure. Curr. Opin. Lipidol. 20 (2), 98-105. doi: 10.1097/MOL.0b013e328328d0a4

Cao, S., Zhou, Y., Xu, P., Wang, Y., Yan, J., Bin, W., et al. (2013). Berberine metabolites exhibit triglyceride-lowering effects via activation of AMP-activated protein kinase in Hep G2 cells. J. Ethnopharmacol. 149 (2), 576-582. doi: 10.1016/j.jep.2013.07.025

Cao, H., Tuo, L., Tuo, Y., Xia, Z., Fu, R., Liu, Y., et al. (2017). Immune and Metabolic Regulation Mechanism of Dangguiliuhuang Decoction against Insulin Resistance and Hepatic Steatosis. Front. Pharmacol. 8, 445. doi: 10.3389/fphar.2017.00445

Cao, H., Li, S., Xie, R., Xu, N., Qian, Y., Chen, H., et al. (2018). Exploring the Mechanism of Dangguiliuhuang Decoction Against Hepatic Fibrosis by Network Pharmacology and Experimental Validation. Front. Pharmacol. 9, 187. doi: 10.3389/fphar.2018.00187

Chao, H. W., Chao, S. W., Lin, H., Ku, H. C., and Cheng, C. F. (2019). Homeostasis of Glucose and Lipid in Non-Alcoholic Fatty Liver Disease. Int. J. Mol. Sci. 20 (2). doi: 10.3390/ijms20020298

Charytoniuk, T., Drygalski, K., Konstantynowicz-Nowicka, K., Berk, K., and Chabowski, A. (2017). Alternative treatment methods attenuate the development of NAFLD: A review of resveratrol molecular mechanisms and clinical trials. Nutrition 34, 108-117. doi: 10.1016/j.nut.2016.09.001

Chatterjee, C., and Sparks, D. L. (2011). Hepatic lipase, high density lipoproteins, and hypertriglyceridemia. Am. J. Pathol. 178 (4), 1429-1433. doi: 10.1016/ j.ajpath.2010.12.050
Choi, J. Y., Kwon, E. Y., and Choi, M. S. (2019). Elucidation of the Metabolic and Transcriptional Responses of an Oriental Herbal Medicine, Bangpungtongseongsan, to Nonalcoholic Fatty Liver Disease in Diet-Induced Obese Mice. J. Med. Food 22 (9), 928-936. doi: 10.1089/jmf.2018.4383

Cui, Y., Chang, R., Zhang, T., Zhou, X., Wang, Q., Gao, H., et al. (2019). Chinese Herbal Formula (CHF03) Attenuates Non-Alcoholic Fatty Liver Disease (NAFLD) Through Inhibiting Lipogenesis and Anti-Oxidation Mechanisms. Front. Pharmacol. 10, 1190. doi: 10.3389/fphar.2019.01190

Czaja, M. J. (2016). Function of Autophagy in Nonalcoholic Fatty Liver Disease. Dig. Dis. Sci. 61 (5), 1304-1313. doi: 10.1007/s10620-015-4025-x

Dang, Y., Hao, S., Zhou, W., Zhang, L., and Ji, G. (2019). The traditional Chinese formulae Ling-gui-zhu-gan decoction alleviated non-alcoholic fatty liver disease via inhibiting PPP1R3C mediated molecules. BMC Complement Altern. Med. 19 (1), 8. doi: 10.1186/s12906-018-2424-1

Dong, H., Lu, F. E., and Zhao, L. (2012). Chinese herbal medicine in the treatment of nonalcoholic fatty liver disease. Chin. J. Integr. Med. 18 (2), 152-160. doi: 10.1007/s11655-012-0993-2

Eissing, L., Scherer, T., Todter, K., Knippschild, U., Greve, J. W., Buurman, W. A., et al. (2013). De novo lipogenesis in human fat and liver is linked to ChREBPbeta and metabolic health. Nat. Commun. 4, 1528. doi: 10.1038/ncomms2537

Feng, Q., Liu, W., Baker, S. S., Li, H., Chen, C., Liu, Q., et al. (2017). Multitargeting therapeutic mechanisms of the Chinese herbal medicine QHD in the treatment of non-alcoholic fatty liver disease. Oncotarget 8 (17), 27820-27838. doi: 10.18632/oncotarget.15482

Feng, W. W., Kuang, S. Y., Tu, C., Ma, Z. J., Pang, J. Y., Wang, Y. H., et al. (2018). Natural products berberine and curcumin exhibited better ameliorative effects on rats with non-alcohol fatty liver disease than lovastatin. BioMed. Pharmacother. 99, 325-333. doi: 10.1016/j.biopha.2018.01.071

Fernandez-Marcos, P. J., and Auwerx, J. (2011). Regulation of PGC-1alpha, a nodal regulator of mitochondrial biogenesis. Am. J. Clin. Nutr. 93 (4), 884S-8890.

Furuhashi, M., and Hotamisligil, G. S. (2008). Fatty acid-binding proteins: role in metabolic diseases and potential as drug targets. Nat. Rev. Drug Discovery 7 (6), 489-503. doi: 10.1038/nrd2589

Guo, X., Cui, R., Zhao, J., Mo, R., Peng, L., and Yan, M. (2016). Corosolic acid protects hepatocytes against ethanol-induced damage by modulating mitogenactivated protein kinases and activating autophagy. Eur. J. Pharmacol. 791, 578-588. doi: 10.1016/j.ejphar.2016.09.031

Guo, Y., Li, J. X., Mao, T. Y., Zhao, W. H., Liu, L. J., and Wang, Y. L. (2017). Targeting Sirt1 in a rat model of high-fat diet-induced non-alcoholic fatty liver disease: Comparison of Gegen Qinlian decoction and resveratrol. Exp. Ther. Med. 14 (5), 4279-4287. doi: 10.3892/etm.2017.5076

Hasan, M., and Bae, H. (2017). "An Overview of Stress-Induced Resveratrol Synthesis in Grapes: Perspectives for Resveratrol-Enriched Grape Products. Molecules 22 (2). doi: 10.3390/molecules22020294

Heeboll, S., Vilstrup, H., and Gronbaek, H. (2018). “[Treatment of non-alcoholic fatty liver disease]. Ugeskr Laeger 180 (31).

Ho, C., Gao, Y., Zheng, D., Liu, Y., Shan, S., Fang, B., et al. (2019). Alisol A attenuates high-fat-diet-induced obesity and metabolic disorders via the AMPK/ACC/SREBP-1c pathway. J. Cell Mol. Med. 23 (8), 5108-5118. doi: $10.1111 /$ jcmm. 14380

Hormati, A., Tooiserkany, F., Mohammadbeigi, A., Aliasl, F., and Dehnavi, H. M. (2019). Effect of an Herbal Product on the Serum Level of Liver Enzymes in Patients with Non-Alcoholic Fatty Liver Disease: A Randomized, DoubleBlinded, Placebo-Controlled Trial. Iranian Red Crescent Med. J. 21 (7), 7. doi: 10.5812/ircmj.91024

Houten, S. M., and Wanders, R. J. (2010). A general introduction to the biochemistry of mitochondrial fatty acid beta-oxidation. J. Inherit. Metab. Dis. 33 (5), 469-477. doi: 10.1007/s10545-010-9061-2

Hsu, W. H., Chen, T. H., Lee, B. H., Hsu, Y. W., and Pan, T. M. (2014). Monascin and ankaflavin act as natural AMPK activators with PPARalpha agonist activity to down-regulate nonalcoholic steatohepatitis in high-fat dietfed C57BL/6 mice. Food Chem. Toxicol. 64, 94-103. doi: 10.1016/ j.fct.2013.11.015 
Huang, L., Cheng, Y., Huang, K., Zhou, Y., Ma, Y., and Zhang, M. (2018). Ameliorative effect of Sedum sarmentosum Bunge extract on Tilapia fatty liver via the PPAR and P53 signaling pathway. Sci. Rep. 8 (1), 8456

Huang, X., Chen, W., Yan, C., Yang, R., Chen, Q., Xu, H., et al. (2019). Gypenosides improve the intestinal microbiota of non-alcoholic fatty liver in mice and alleviate its progression. BioMed. Pharmacother. 118, 109258. doi: 10.1016/j.biopha.2019.109258

Huu Tung, N., Uto, T., Morinaga, O., Kim, Y. H., and Shoyama, Y. (2012). Pharmacological effects of ginseng on liver functions and diseases: a minireview. Evid. Based Complement Alternat. Med. 2012, 173297.

Ibrahim, S. H., Hirsova, P., Malhi, H., and Gores, G. J. (2016). Animal Models of Nonalcoholic Steatohepatitis: Eat, Delete, and Inflame. Dig. Dis. Sci. 61 (5), 1325-1336. doi: 10.1007/s10620-015-3977-1

Ipsen, D. H., Lykkesfeldt, J., and Tveden-Nyborg, P. (2018). Molecular mechanisms of hepatic lipid accumulation in non-alcoholic fatty liver disease. Cell Mol. Life Sci. 75 (18), 3313-3327. doi: 10.1007/s00018-018-2860-6

Issa, D., Patel, V., and Sanyal, A. J. (2018). Future therapy for non-alcoholic fatty liver disease. Liver Int. 38 Suppl 1, 56-63. doi: 10.1111/liv.13676

Jang, J., Jung, Y., Chae, S., Cho, S. H., Yoon, M., Yang, H., et al. (2018). Gangjihwan, a polyherbal composition, inhibits fat accumulation through the modulation of lipogenic transcription factors SREBP1C, PPARgamma and C/EBPalpha. J. Ethnopharmacol. 210, 10-22. doi: 10.1016/j.jep.2017.08.024

Jung, H. Y., Lee, D., Ryu, H. G., Choi, B. H., Go, Y., Lee, N., et al. (2017). Myricetin improves endurance capacity and mitochondrial density by activating SIRT1 and PGC-1alpha. Sci. Rep. 7 (1), 6237.

Kang, H., and Koppula, S. (2014). Houttuynia cordata attenuates lipid accumulation via activation of AMP-activated protein kinase signaling pathway in HepG2 cells. Am. J. Chin. Med. 42 (3), 651-664. doi: 10.1142/ S0192415X14500426

Kang, O. H., Kim, S. B., Mun, S. H., Seo, Y. S., Hwang, H. C., Lee, Y. M., et al. (2015). Puerarin ameliorates hepatic steatosis by activating the PPARalpha and AMPK signaling pathways in hepatocytes. Int. J. Mol. Med. 35 (3), 803-809. doi: 10.3892/ijmm.2015.2074

Kawano, Y., and Cohen, D. E. (2013). Mechanisms of hepatic triglyceride accumulation in non-alcoholic fatty liver disease. J. Gastroenterol. 48 (4), 434-441. doi: 10.1007/s00535-013-0758-5

Khalil, M., Khalifeh, H., Baldini, F., Salis, A., Damonte, G., Daher, A., et al. (2019). Antisteatotic and antioxidant activities of Thymbra spicata L. extracts in hepatic and endothelial cells as in vitro models of non-alcoholic fatty liver disease. J. Ethnopharmacol. 239, 111919.

Khavasi, N., Somi, M. H., Khadem, E., Faramarzi, E., Ayati, M. H., Fazljou, S. M. B., et al. (2017). Effect of Daily Caper Fruit Pickle Consumption on Disease Regression in Patients with Non-Alcoholic Fatty Liver Disease: a Double-Blinded Randomized Clinical Trial. Adv. Pharm. Bull. 7 (4), 645-650. doi: 10.15171/apb.2017.077

Kounakis, K., Chaniotakis, M., Markaki, M., and Tavernarakis, N. (2019). Emerging Roles of Lipophagy in Health and Disease. Front. Cell Dev. Biol. 7, 185. doi: $10.3389 /$ fcell.2019.00185

Kumashiro, N., Yoshimura, T., Cantley, J. L., Majumdar, S. K., Guebre-Egziabher, F., Kursawe, R., et al. (2013). Role of patatin-like phospholipase domain-containing 3 on lipid-induced hepatic steatosis and insulin resistance in rats. Hepatology 57 (5), 1763-1772. doi: 10.1002/hep.26170

Kwanten, W. J., Martinet, W., Michielsen, P. P., and Francque, S. M. (2014). Role of autophagy in the pathophysiology of nonalcoholic fatty liver disease: a controversial issue. World J. Gastroenterol. 20 (23), 7325-7338. doi: 10.3748/wjg.v20.i23.7325

Lamichane, S., Dahal Lamichane, B., and Kwon, S. M. (2018). Pivotal Roles of Peroxisome Proliferator-Activated Receptors (PPARs) and Their Signal Cascade for Cellular and Whole-Body Energy Homeostasis. Int. J. Mol. Sci. 19 (4). doi: 10.3390/ijms19040949

Lass, A., Zimmermann, R., Oberer, M., and Zechner, R. (2011). Lipolysis - a highly regulated multi-enzyme complex mediates the catabolism of cellular fat stores. Prog. Lipid Res. 50 (1), 14-27. doi: 10.1016/j.plipres.2010.10.004

Lee, J. E., Kim, E. J., Kim, M. H., Hong, J., and Yang, W. M. (2016). Polygonatum stenophyllum improves menopausal obesity via regulation of lipolysis-related enzymes. J. Nat. Med. 70 (4), 789-796. doi: 10.1007/s11418-016-1018-9

Lee, Y. H., Jin, B., Lee, S. H., Song, M., Bae, H., Min, B. J., et al. (2016). Herbal Formula HT048 Attenuates Diet-Induced Obesity by Improving Hepatic Lipid
Metabolism and Insulin Resistance in Obese Rats". Molecules 21 (11). doi: 10.3390/molecules21111424

Lee, J. H., Baek, S. Y., Jang, E. J., Ku, S. K., Kim, K. M., Ki, S. H., et al. (2018). Oxyresveratrol ameliorates nonalcoholic fatty liver disease by regulating hepatic lipogenesis and fatty acid oxidation through liver kinase B1 and AMP-activated protein kinase. Chem. Biol. Interact. 289, 68-74. doi: 10.1016/j.cbi.2018.04.023

Li, X., Li, Z., Xue, M., Ou, Z., Liu, M., Yang, M., et al. (2013). Fructus Xanthii attenuates hepatic steatosis in rats fed on high-fat diet. PloS One 8 (4), e61499. doi: 10.1371/journal.pone.0061499

Li, W., Li, Y., Wang, Q., and Yang, Y. (2014). Crude extracts from Lycium barbarum suppress SREBP-1c expression and prevent diet-induced fatty liver through AMPK activation. BioMed. Res. Int. 2014, 196198.

Li, Y., Zhao, J., Zheng, H., Zhong, X., Zhou, J., and Hong, Z. (2014). Treatment of Nonalcoholic Fatty Liver Disease with Total Alkaloids in Rubus aleaefolius Poir through Regulation of Fat Metabolism. Evid. Based Complement Alternat. Med. 2014, 768540. doi: 10.1155/2014/768540

Li, Z., Xu, J., Zheng, P., Xing, L., Shen, H., Yang, L., et al. (2015). Hawthorn leaf flavonoids alleviate nonalcoholic fatty liver disease by enhancing the adiponectin/AMPK pathway. Int. J. Clin. Exp. Med. 8 (10), 17295-17307.

Li, W. S., Wu, Y., Ge, W. Z., Fan, L., and Sun, W. (2017). A herbal formula Erchen decoction for non-alcoholic fatty liver disease: a systematic review and meta-analysis of randomized controlled trials. Int. J. Clin. Exp. Med. 10 (6), 9110-9116.

Li, C. H., Tang, S. C., Wong, C. H., Wang, Y., Jiang, J. D., and Chen, Y. (2018). Berberine induces miR-373 expression in hepatocytes to inactivate hepatic steatosis associated AKT-S6 kinase pathway. Eur. J. Pharmacol. 825, 107-118. doi: 10.1016/j.ejphar.2018.02.035

Li, Y. Y., Tang, D., Du, Y. L., Cao, C. Y., Nie, Y. Q., Cao, J., et al. (2018). Fatty liver mediated by peroxisome proliferator-activated receptor-alpha DNA methylation can be reversed by a methylation inhibitor and curcumin. J. Dig. Dis. 19 (7), 421-430. doi: 10.1111/1751-2980.12610

Li, Y. Y., Chen, M., Wang, J., Guo, X. P., Xiao, L., Liu, P. Y., et al. (2019). Quercetin ameliorates autophagy in alcohol liver disease associated with lysosome through mTOR-TFEB pathway. J. Funct. Foods 52, 177-185. doi: 10.1016/j.jff.2018.10.033

Liang, Z. E., Zhang, Y. P., Tang, K. R., Deng, Y. J., Liang, Y. Q., Liang, S., et al. (2019). Anti-inflammation effect via TLR4-mediated MyD88-dependent and -independent signalling pathways in non-alcoholic fatty liver disease rats: Chinese herb formula. Int. J. Clin. Exp. Med. 12 (3), 2265-2277.

Liao, C. C., Ou, T. T., Huang, H. P., and Wang, C. J. (2014). The inhibition of oleic acid induced hepatic lipogenesis and the promotion of lipolysis by caffeic acid via upregulation of AMP-activated kinase. J. Sci. Food Agric. 94 (6), 1154-1162. doi: 10.1002/jsfa.6386

Lim, J., Lee, H., Ahn, J., Kim, J., Jang, J., Park, Y., et al. (2018). The polyherbal drug GGEx18 from Laminaria japonica, Rheum palmatum, and Ephedra sinica inhibits hepatic steatosis and fibroinflammtion in high-fat diet-induced obese mice. J. Ethnopharmacol. 225, 31-41. doi: 10.1016/j.jep.2018.06.034

Liu, K., and Czaja, M. J. (2013). Regulation of lipid stores and metabolism by lipophagy. Cell Death Differ. 20 (1), 3-11. doi: 10.1038/cdd.2012.63

Liu, L., Yang, M., Lin, X., Li, Y., Liu, C., Yang, Y., et al. (2013). Modulation of hepatic sterol regulatory element-binding protein-1c-mediated gene expression contributes to Salacia oblonga root-elicited improvement of fructose-induced fatty liver in rats. J. Ethnopharmacol. 150 (3), 1045-1052. doi: 10.1016/j.jep.2013.10.020

Liu, Z. L., Xie, L. Z., Zhu, J., Li, G. Q., Grant, S. J., and Liu, J. P. (2013). Herbal medicines for fatty liver diseases. Cochrane Database Syst. Rev. (8), CD009059. doi: 10.1002/14651858.CD009059.pub2

Liu, Q., Zhu, L., Cheng, C., Hu, Y. Y., and Feng, Q. (2017). Natural Active Compounds from Plant Food and Chinese Herbal Medicine for Nonalcoholic Fatty Liver Disease. Curr. Pharm. Des. 23 (34), 5136-5162.

Liu, X., Tong, W., Zhao, X., Zhang, H., Tang, Y., and Deng, X. (2017). Chinese herb extract improves liver steatosis by promoting the expression of high molecular weight adiponectin in NAFLD rats. Mol. Med. Rep. 16 (4), 5580-5586. doi: 10.3892/ mmr.2017.7284

Liu, Y. L., Lin, L. C., Tung, Y. T., Ho, S. T., Chen, Y. L., Lin, C. C., et al. (2017). Rhododendron oldhamii leaf extract improves fatty liver syndrome by increasing lipid oxidation and decreasing the lipogenesis pathway in mice. Int. J. Med. Sci. 14 (9), 862-870. doi: 10.7150/ijms.19553 
Liu, X., Xie, Z. H., Liu, C. Y., and Zhang, Y. (2019). Effect of Chinese Herbal Monomer Hairy Calycosin on Nonalcoholic Fatty Liver Rats and its Mechanism. Comb. Chem. High Throughput Screen 22 (3), 194-200. doi: 10.2174/1386207322666190411112814

Liu, Y. Y., You, J. J., Xu, W., Zhai, T., Du, C. Y., Chen, Y., et al. (2019). Gynura procumbens aqueous extract alleviates nonalcoholic steatohepatitis through CFLAR-JNK pathway in vivo and in vitro. Chin. Herb. Medicines 11 (4), 369-378. doi: 10.1016/j.chmed.2019.09.005

Lo, V., Erickson, B., Thomason-Hughes, M., Ko, K. W., Dolinsky, V. W., Nelson, R., et al. (2010). Arylacetamide deacetylase attenuates fatty-acid-induced triacylglycerol accumulation in rat hepatoma cells. J. Lipid Res. 51 (2), 368-377. doi: 10.1194/ jlr.M000596

Lomonaco, R., Sunny, N. E., Bril, F., and Cusi, K. (2013). Nonalcoholic fatty liver disease: current issues and novel treatment approaches. Drugs 73 (1), 1-14. doi: 10.1007/s40265-012-0004-0

Lu, X., Yuan, Z. Y., Yan, X. J., Lei, F., Jiang, J. F., Yu, X., et al. (2016). Effects of Angelica dahurica on obesity and fatty liver in mice. Chin. J. Nat. Med. 14 (9), 641-652. doi: 10.1016/S1875-5364(16)30076-0

Luan, H., Huo, Z., Zhao, Z., Zhang, S., Huang, Y., Shen, Y., et al. (2019). Scutellarin, a modulator of mTOR, attenuates hepatic insulin resistance by regulating hepatocyte lipid metabolism via SREBP-1c suppression. Phytother. Res. doi: 10.1002/ptr.6582

Ma, J., Zhao, D., Wang, X., Ma, C., Feng, K., Zhang, S., et al. (2019). LongShengZhi Capsule Reduces Established Atherosclerotic Lesions in apoE-Deficient Mice by Ameliorating Hepatic Lipid Metabolism and Inhibiting Inflammation. J. Cardiovasc. Pharmacol. 73 (2), 105-117. doi: 10.1097/FJC.0000000000000642

Mandal, S., Mukhopadhyay, S., Bandhopadhyay, S., Sen, G., and Biswas, T. (2014). 14-Deoxyandrographolide alleviates ethanol-induced hepatosteatosis through stimulation of AMP-activated protein kinase activity in rats. Alcohol 48 (2), 123-132. doi: 10.1016/j.alcohol.2013.11.005

Mato, J. M., Alonso, C., Noureddin, M., and Lu, S. C. (2019). Biomarkers and subtypes of deranged lipid metabolism in non-alcoholic fatty liver disease. World J. Gastroenterol. 25 (24), 3009-3020. doi: 10.3748/wjg.v25.i24.3009

Meng, Q., Duan, X. P., Wang, C. Y., Liu, Z. H., Sun, P. Y., Huo, X. K., et al. (2017). Alisol B 23-acetate protects against non-alcoholic steatohepatitis in mice via farnesoid X receptor activation. Acta Pharmacol. Sin. 38 (1), 69-79. doi: 10.1038/aps.2016.119

Moctezuma-Velazquez, C. (2018). Current treatment for non-alcoholic fatty liver disease. Rev. Gastroenterol. Mex. 83 (2), 125-133. doi: 10.1016/j.rgmxen.2018.05.014

Musso, G., Gambino, R., and Cassader, M. (2009). Recent insights into hepatic lipid metabolism in non-alcoholic fatty liver disease (NAFLD). Prog. Lipid Res. 48 (1), 1-26. doi: 10.1016/j.plipres.2008.08.001

Nguyen, P., Leray, V., Diez, M., Serisier, S., Le Bloc'h, J., Siliart, B., et al. (2008). Liver lipid metabolism. J. Anim. Physiol. Anim. Nutr. (Berl.) 92 (3), 272-283. doi: 10.1111/j.1439-0396.2007.00752.x

Ouali, F., Djouadi, F., Merlet-Benichou, C., Riveau, B., and Bastin, J. (2000). Regulation of fatty acid transport protein and mitochondrial and peroxisomal beta-oxidation gene expression by fatty acids in developing rats. Pediatr. Res. 48 (5), 691-696. doi: 10.1203/00006450-200011000-00023

Parafati, M., Lascala, A., Morittu, V. M., Trimboli, F., Rizzuto, A., Brunelli, E., et al. (2015). Bergamot polyphenol fraction prevents nonalcoholic fatty liver disease via stimulation of lipophagy in cafeteria diet-induced rat model of metabolic syndrome. J. Nutr. Biochem. 26 (9), 938-948. doi: 10.1016/j.jnutbio.2015.03.008

Park, H., Kaushik, V. K., Constant, S., Prentki, M., Przybytkowski, E., Ruderman, N. B., et al. (2002). Coordinate regulation of malonyl-CoA decarboxylase, snglycerol-3-phosphate acyltransferase, and acetyl-CoA carboxylase by AMPactivated protein kinase in rat tissues in response to exercise. J. Biol. Chem. 277 (36), 32571-32577. doi: 10.1074/jbc.M201692200

Park, H. J., Han, J. M., Kim, H. G., Choi, M. K., Lee, J. S., Lee, H. W., et al. (2013). Chunggan extract (CGX), methionine-and choline-deficient (MCD) dietinduced hepatosteatosis and oxidative stress in C57BL/6 mice. Hum. Exp. Toxicol. 32 (12), 1258-1269. doi: 10.1177/0960327113485253

Park, H., Hwang, Y. H., Kim, D. G., Jeon, J., and Ma, J. Y. (2015). Hepatoprotective effect of herb formula KIOM2012H against nonalcoholic fatty liver disease. Nutrients 7 (4), 2440-2455. doi: 10.3390/nu7042440
Park, T. Y., Hong, M., Sung, H., Kim, S., and Suk, K. T. (2017). Effect of Korean Red Ginseng in chronic liver disease. J. Ginseng Res. 41 (4), 450-455. doi: 10.1016/j.jgr.2016.11.004

Peng, C. H., Liu, L. K., Chuang, C. M., Chyau, C. C., Huang, C. N., and Wang, C. J. (2011). Mulberry water extracts possess an anti-obesity effect and ability to inhibit hepatic lipogenesis and promote lipolysis. J. Agric. Food Chem. 59 (6), 2663-2671. doi: 10.1021/jf1043508

Peng, H., He, Y., Zheng, G., Zhang, W., Yao, Z., and Xie, W. (2016). Meta-analysis of traditional herbal medicine in the treatment of nonalcoholic fatty liver disease. Cell Mol. Biol. (Noisy-le-grand) 62 (4), 88-95.

Perla, F. M., Prelati, M., Lavorato, M., Visicchio, D., and Anania, C. (2017). The Role of Lipid and Lipoprotein Metabolism in Non-Alcoholic Fatty Liver Disease. Children (Basel) 4 (6). doi: 10.3390/children4060046

Perumpail, B. J., Li, A. A., Iqbal, U., Sallam, S., Shah, N. D., Kwong, W., et al. (2018). Potential Therapeutic Benefits of Herbs and Supplements in Patients with NAFLD. Diseases 6 (3). doi: 10.3390/diseases6030080

Pierre, G., Macdonald, A., Gray, G., Hendriksz, C., Preece, M. A., and Chakrapani, A. (2007). Prospective treatment in carnitine-acylcarnitine translocase deficiency. J. Inherit. Metab. Dis. 30 (5), 815. doi: 10.1007/ s10545-007-0518-x

Pil Hwang, Y., Gyun Kim, H., Choi, J. H., Truong Do, M., Tran, T. P., Chun, H. K., et al. (2013). 3-Caffeoyl, 4-dihydrocaffeoylquinic acid from Salicornia herbacea attenuates high glucose-induced hepatic lipogenesis in human HepG2 cells through activation of the liver kinase B1 and silent information regulator T1/ AMPK-dependent pathway. Mol. Nutr. Food Res. 57 (3), 471-482. doi: 10.1002/mnfr.201200529

Ponziani, F. R., Pecere, S., Gasbarrini, A., and Ojetti, V. (2015). Physiology and pathophysiology of liver lipid metabolism. Expert Rev. Gastroenterol. Hepatol. 9 (8), 1055-1067. doi: 10.1586/17474124.2015.1056156

Qian, W., Cai, X., Zhang, X., Wang, Y., Qian, Q., and Hasegawa, J. (2016). Effect of Daisaikoto on Expressions of SIRT1 and NF-kappaB of Diabetic Fatty Liver Rats Induced by High-Fat Diet and Streptozotocin. Yonago Acta Med. 59 (2), 149-158.

Qiu, P., Li, X., Kong, D. S., Li, H. Z., Niu, C. C., and Pan, S. H. (2015). Herbal SGR Formula Prevents Acute Ethanol-Induced Liver Steatosis via Inhibition of Lipogenesis and Enhancement Fatty Acid Oxidation in Mice. Evid. Based Complement Alternat. Med. 2015, 613584. doi: 10.1155/2015/613584

Quiroga, A. D., and Lehner, R. (2018). Pharmacological intervention of liver triacylglycerol lipolysis: The good, the bad and the ugly. Biochem. Pharmacol. 155, 233-241. doi: 10.1016/j.bcp.2018.07.005

Reddy, J. K., and Rao, M. S. (2006). Lipid metabolism and liver inflammation. II. Fatty liver disease and fatty acid oxidation. Am. J. Physiol. Gastrointest Liver Physiol. 290 (5), G852-G858.

Ren, L., Sun, D., Zhou, X., Yang, Y., Huang, X., Li, Y., et al. (2019). Chronic treatment with the modified Longdan Xiegan Tang attenuates olanzapine-induced fatty liver in rats by regulating hepatic de novo lipogenesis and fatty acid beta-oxidationassociated gene expression mediated by SREBP-1c, PPAR-alpha and AMPK-alpha. J. Ethnopharmacol. 232, 176-187. doi: 10.1016/j.jep.2018.12.034

Roh, J. S., Lee, H., Lim, J., Kim, J., Yang, H., Yoon, Y., et al. (2017). Effect of Gangjihwan on hepatic steatosis and inflammation in high fat diet-fed mice. J. Ethnopharmacol. 206, 315-326. doi: 10.1016/j.jep.2017.06.008

Rui, L. (2014). Energy metabolism in the liver. Compr. Physiol. 4 (1), 177-197. doi: $10.1002 /$ cphy.c130024

Saha, A. K., and Ruderman, N. B. (2003). Malonyl-CoA and AMP-activated protein kinase: an expanding partnership. Mol. Cell Biochem. 253 (1-2), 65-70. doi: 10.1023/A:1026053302036

Seo, M. S., Hong, S. W., Yeon, S. H., Kim, Y. M., Um, K. A., Kim, J. H., et al. (2014). Magnolia officinalis attenuates free fatty acid-induced lipogenesis via AMPK phosphorylation in hepatocytes. J. Ethnopharmacol. 157, 140-148. doi: 10.1016/j.jep.2014.09.031

Shang, J., Chen, L. L., Xiao, F. X., Sun, H., Ding, H. C., and Xiao, H. (2008). Resveratrol improves non-alcoholic fatty liver disease by activating AMPactivated protein kinase. Acta Pharmacol. Sin. 29 (6), 698-706. doi: 10.1111/ j.1745-7254.2008.00807.x

Sheng, X., Wang, M., Lu, M., Xi, B., Sheng, H., and Zang, Y. Q. (2011). Rhein ameliorates fatty liver disease through negative energy balance, hepatic 
lipogenic regulation, and immunomodulation in diet-induced obese mice. Am. J. Physiol. Endocrinol. Metab. 300 (5), E886-E893. doi: 10.1152/ ajpendo.00332.2010

Sheng, D., Zhao, S., Gao, L., Zheng, H., Liu, W., Hou, J., et al. (2019). BabaoDan attenuates high-fat diet-induced non-alcoholic fatty liver disease via activation of AMPK signaling. Cell Biosci. 9, 77. doi: 10.1186/s13578-019-0339-2

Shi, K. Q., Fan, Y. C., Liu, W. Y., Li, L. F., Chen, Y. P., and Zheng, M. H. (2012). Traditional Chinese medicines benefit to nonalcoholic fatty liver disease: a systematic review and meta-analysis. Mol. Biol. Rep. 39 (10), 9715-9722. doi: 10.1007/s11033-012-1836-0

Shi, L. J., Shi, L., Song, G. Y., Zhang, H. F., Hu, Z. J., Wang, C., et al. (2013). Oxymatrine attenuates hepatic steatosis in non-alcoholic fatty liver disease rats fed with high fructose diet through inhibition of sterol regulatory element binding transcription factor 1 (Srebf1) and activation of peroxisome proliferator activated receptor alpha (Pparalpha). Eur. J. Pharmacol. 714 (1-3), 89-95. doi: 10.1016/j.ejphar.2013.06.013

Shi, X., Sun, R. M., Zhao, Y., Fu, R., Wang, R. W., Zhao, H. Y., et al. (2018). Promotion of autophagosome-lysosome fusion via salvianolic acid A-mediated SIRT1 up-regulation ameliorates alcoholic liver disease. Rsc Adv. 8 (36), 20411-20422. doi: 10.1039/C8RA00798E

Singh, R., and Cuervo, A. M. (2012). Lipophagy: connecting autophagy and lipid metabolism. Int. J. Cell Biol. 2012, 282041. doi: 10.1155/2012/282041

Sun, F., Xie, M. L., Zhu, L. J., Xue, J., and Gu, Z. L. (2009). Inhibitory effect of osthole on alcohol-induced fatty liver in mice. Dig. Liver Dis. 41 (2), 127-133. doi: 10.1016/j.dld.2008.01.011

Sun, X. H., Zhang, L. D., and Wei, W. (2019). A study on the mechanism of adipokine in non-alcoholic fatty liver in rats treated by four herbs decoction. Eur. J. Inflammation 17, 8. doi: 10.1177/2058739219853970

Tessari, P., Coracina, A., Cosma, A., and Tiengo, A. (2009). Hepatic lipid metabolism and non-alcoholic fatty liver disease. Nutr. Metab. Cardiovasc. Dis. 19 (4), 291-302. doi: 10.1016/j.numecd.2008.12.015

Theodotou, M., Fokianos, K., Moniatis, D., Kadlenic, R., Chrysikou, A., Aristotelous, A., et al. (2019). Effect of resveratrol on non-alcoholic fatty liver disease. Exp. Ther. Med. 18 (1), 559-565. doi: 10.3892/etm.2019.7607

Uen, W. C., Shi, Y. C., Choong, C. Y., and Tai, C. J. (2018). Cordycepin suppressed lipid accumulation via regulating AMPK activity and mitochondrial fusion in hepatocytes. J. Food Biochem. 42 (5), 7. doi: 10.1111/jfbc.12569

Veeramani, C., Alsaif, M. A., and Al-Numair, K. S. (2017). Lavatera critica, a green leafy vegetable, controls high fat diet induced hepatic lipid accumulation and oxidative stress through the regulation of lipogenesis and lipolysis genes. BioMed. Pharmacother. 96, 1349-1357. doi: 10.1016/j.biopha.2017.11.072

Veeramani, C., Alsaif, M. A., and Al-Numair, K. S. (2018). Herbacetin, a flaxseed flavonoid, ameliorates high percent dietary fat induced insulin resistance and lipid accumulation through the regulation of hepatic lipid metabolizing and lipidregulating enzymes. Chem. Biol. Interact. 288, 49-56. doi: 10.1016/j.cbi.2018.04.009

Wanders, R. J., Waterham, H. R., and Ferdinandusse, S. (2015). Metabolic Interplay between Peroxisomes and Other Subcellular Organelles Including Mitochondria and the Endoplasmic Reticulum. Front. Cell Dev. Biol. 3, 83.

Wang, Y. L., Liu, L. J., Zhao, W. H., and Li, J. X. (2015). Intervening TNF-alpha via PPARgamma with Gegenqinlian Decoction in Experimental Nonalcoholic Fatty Liver Disease. Evid. Based Complement Alternat. Med. 2015, 715638.

Wang, Y., Viscarra, J., Kim, S. J., and Sul, H. S. (2015). Transcriptional regulation of hepatic lipogenesis. Nat. Rev. Mol. Cell Biol. 16 (11), 678-689. doi: 10.1038/ nrm 4074

Wang, Y. P., Wat, E., Koon, C. M., Wong, C. W., Cheung, D. W., Leung, P. C., et al. (2016). The beneficial potential of polyphenol-enriched fraction from Erigerontis Herba on metabolic syndrome. J. Ethnopharmacol. 187, 94-103. doi: 10.1016/j.jep.2016.04.040

Wang, S. J., Chen, Q., Liu, M. Y., Yu, H. Y., Xu, J. Q., Wu, J. Q., et al. (2019). Regulation effects of rosemary (Rosmarinus officinalis Linn.) on hepatic lipid metabolism in OA induced NAFLD rats. Food Funct. 10 (11), 7356-7365.

Ward, C., Martinez-Lopez, N., Otten, E. G., Carroll, B., Maetzel, D., Singh, R., et al. (2016). Autophagy, lipophagy and lysosomal lipid storage disorders. Biochim. Biophys. Acta 1861 (4), 269-284. doi: 10.1016/j.bbalip.2016.01.006

$\mathrm{Wu}, \mathrm{W}$. Y., and Wang, Y. P. (2012). Pharmacological actions and therapeutic applications of Salvia miltiorrhiza depside salt and its active components. Acta Pharmacol. Sin. 33 (9), 1119-1130. doi: 10.1038/aps.2012.126
Xiao, J., Fai So, K., Liong, E. C., and Tipoe, G. L. (2013). Recent advances in the herbal treatment of non-alcoholic Fatty liver disease. J. Tradit. Complement Med. 3 (2), 88-94. doi: 10.4103/2225-4110.110411

Xu, L., Yin, L., Tao, X., Qi, Y., Han, X., Xu, Y., et al. (2017). Dioscin, a potent ITGA5 inhibitor, reduces the synthesis of collagen against liver fibrosis: Insights from SILAC-based proteomics analysis. Food Chem. Toxicol. $107(\mathrm{Pt}$ A), 318-328. doi: 10.1016/j.fct.2017.07.014

Yan, S., Khambu, B., Hong, H., Liu, G., Huda, N., and Yin, X. M. (2019). Autophagy, Metabolism, and Alcohol-Related Liver Disease: Novel Modulators and Functions. Int. J. Mol. Sci. 20 (20). doi: 10.3390/ ijms 20205029

Yang, W., She, L., Yu, K., Yan, S., Zhang, X., Tian, X., et al. (2016). Jatrorrhizine hydrochloride attenuates hyperlipidemia in a high-fat diet-induced obesity mouse model. Mol. Med. Rep. 14 (4), 3277-3284. doi: 10.3892/mmr.2016.5634

Yang, L., Lin, W., Nugent, C. A., Hao, S., Song, H., Liu, T., et al. (2017). Lingguizhugan Decoction Protects against High-Fat-Diet-Induced Nonalcoholic Fatty Liver Disease by Alleviating Oxidative Stress and Activating Cholesterol Secretion. Int. J. Genomics 2017, 2790864. doi: 10.1155/ $2017 / 2790864$

Yang, J. M., Sun, Y., Wang, M., Zhang, X. L., Zhang, S. J., Gao, Y. S., et al. (2019). Regulatory effect of a Chinese herbal medicine formula on non-alcoholic fatty liver disease. World J. Gastroenterol. 25 (34), 5105-5119. doi: 10.3748/ wjg.v25.i34.5105

Yang, L., Yang, C., Thomes, P. G., Kharbanda, K. K., Casey, C. A., McNiven, M. A. et al. (2019). Lipophagy and Alcohol-Induced Fatty Liver. Front. Pharmacol. 10, 495. doi: 10.3389/fphar.2019.00495

Yang, X. X., Wang, X., Shi, T. T., Dong, J. C., Li, F. J., Zeng, L. X., et al. (2019). Mitochondrial dysfunction in high-fat diet-induced nonalcoholic fatty liver disease: The alleviating effect and its mechanism of Polygonatum kingianum. BioMed. Pharmacother. 117, 109083. doi: 10.1016/j.biopha.2019. 109083

Yang, Y., Li, J., Wei, C., He, Y., Cao, Y., Zhang, Y., et al. (2019). Amelioration of nonalcoholic fatty liver disease by swertiamarin in fructose-fed mice. Phytomedicine 59, 152782. doi: 10.1016/j.phymed.2018.12.005

Yao, H., Qiao, Y. J., Zhao, Y. L., Tao, X. F., Xu, L. N., Yin, L. H., et al. (2016). Herbal medicines and nonalcoholic fatty liver disease. World J. Gastroenterol. 22 (30), 6890-6905. doi: 10.3748/wjg.v22.i30.6890

Yoon, S., Kim, J., Lee, H., Lee, H., Lim, J., Yang, H., et al. (2017). The effects of herbal composition Gambigyeongsinhwan (4) on hepatic steatosis and inflammation in Otsuka Long-Evans Tokushima fatty rats and HepG2 cells. J. Ethnopharmacol. 195, 204-213. doi: 10.1016/j.jep.2016.11.020

Younossi, Z. M. (2019). Non-alcoholic fatty liver disease - A global public health perspective. J. Hepatol. 70 (3), 531-544. doi: 10.1016/j.jhep.2018.10.033

Yu, S., Rao, S., and Reddy, J. K. (2003). Peroxisome proliferator-activated receptors, fatty acid oxidation, steatohepatitis and hepatocarcinogenesis. Curr. Mol. Med. 3 (6), 561-572. doi: 10.2174/1566524033479537

Zamani, N., Shams, M., Nimrouzi, M., Zarshenas, M. M., Abolhasani Foroughi, A., Fallahzadeh Abarghooei, E., et al. (2018). The effects of Zataria multiflora Boiss. (Shirazi thyme) on nonalcoholic fatty liver disease and insulin resistance: A randomized double-blind placebo-controlled clinical trial. Complement Ther. Med. 41, 118-123. doi: 10.1016/j.ctim.2018.09.010

Zar Kalai, F., Han, J., Ksouri, R., Abdelly, C., and Isoda, H. (2014). Oral administration of Nitraria retusa ethanolic extract enhances hepatic lipid metabolism in $\mathrm{db} / \mathrm{db}$ mice model 'BKS.Cg-Dock7 $(\mathrm{m})+/+\operatorname{Lepr}(\mathrm{db} /) \mathrm{J}$ ' through the modulation of lipogenesis-lipolysis balance. Food Chem. Toxicol. 72, 247256. doi: 10.1016/j.fct.2014.07.029

Zhang, Y., Si, Y., Zhai, L., Yang, N., Yao, S., Sang, H., et al. (2013). Celastrus orbiculatus Thunb. ameliorates high-fat diet-induced non-alcoholic fatty liver disease in guinea pigs. Pharmazie 68 (10), 850-854.

Zhang, Y., Yu, L., Cai, W., Fan, S., Feng, L., Ji, G., et al. (2014). Protopanaxatriol, a novel PPARgamma antagonist from Panax ginseng, alleviates steatosis in mice. Sci. Rep. 4, 7375. doi: 10.1038/srep07375

Zhang, E., Yin, S., Song, X., Fan, L., and Hu, H. (2016). Glycycoumarin inhibits hepatocyte lipoapoptosis through activation of autophagy and inhibition of ER stress/GSK-3-mediated mitochondrial pathway. Sci. Rep. 6, 38138. doi: $10.1038 /$ srep38138 
Zhang, L., Yao, Z., and Ji, G. (2018). Herbal Extracts and Natural Products in Alleviating Non-alcoholic Fatty Liver Disease via Activating Autophagy. Front. Pharmacol. 9, 1459. doi: 10.3389/fphar.2018.01459

Zhang, E., Yin, S., Zhao, S., Zhao, C., Yan, M., Fan, L., et al. (2019). Protective effects of glycycoumarin on liver diseases. Phytother. Res. doi: 10.1002/ptr.6598

Zhang, Y., Liu, M., Chen, Q., Wang, T., Yu, H., Xu, J., et al. (2019). Leaves of Lippia triphylla improve hepatic lipid metabolism via activating AMPK to regulate lipid synthesis and degradation. J. Nat. Med. 73 (4), 707-716. doi: 10.1007/ s11418-019-01316-5

Zheng, Y., Wang, M., Zheng, P., Tang, X., and Ji, G. (2018). Systems pharmacology-based exploration reveals mechanisms of anti-steatotic effects of Jiang Zhi Granule on non-alcoholic fatty liver disease. Sci. Rep. 8 (1), 13681.

Zhong, H., Chen, K., Feng, M., Shao, W., Wu, J., Chen, K., et al. (2018). Genipin alleviates high-fat diet-induced hyperlipidemia and hepatic lipid accumulation in mice via miR-142a-5p/SREBP-1c axis. FEBS J. 285 (3), 501-517. doi: 10.1111/febs.14349

Zhou, W., Rahimnejad, S., Lu, K., Wang, L., and Liu, W. (2019). Effects of berberine on growth, liver histology, and expression of lipid-related genes in blunt snout bream (Megalobrama amblycephala) fed high-fat diets. Fish Physiol. Biochem. 45 (1), 83-91. doi: 10.1007/s10695-018-0536-7

Zhu, M., Hao, S., Liu, T., Yang, L., Zheng, P., Zhang, L., et al. (2017). Lingguizhugan decoction improves non-alcoholic fatty liver disease by altering insulin resistance and lipid metabolism related genes: a whole trancriptome study by RNA-Seq. Oncotarget 8 (47), 82621-82631. doi: 10.18632/oncotarget.19734

Conflict of Interest: The authors declare that the research was conducted in the absence of any commercial or financial relationships that could be construed as a potential conflict of interest.

Copyright (c) $2020 \mathrm{Li}, \mathrm{Xu}$, Guo, Chen, Zhang, Tan, Wang and Feng. This is an openaccess article distributed under the terms of the Creative Commons Attribution License (CC BY). The use, distribution or reproduction in other forums is permitted, provided the original author(s) and the copyright owner(s) are credited and that the original publication in this journal is cited, in accordance with accepted academic practice. No use, distribution or reproduction is permitted which does not comply with these terms. 